\title{
Ideas and perspectives: A strategic assessment of methane and nitrous oxide measurements in the marine environment
}

Samuel T. Wilson ${ }^{1}$, Alia N. Al-Haj ${ }^{2}$, Annie Bourbonnais ${ }^{3}$, Claudia Frey ${ }^{4}$, Robinson W. Fulweiler $^{2,5}$, John D. Kessler ${ }^{6}$ Hannah K. Marchant ${ }^{7}$, Jana Milucka ${ }^{7}$, Nicholas E. Ray ${ }^{5}$, Parvadha Suntharalingam ${ }^{8}$, Brett F. Thornton ${ }^{9}$, Robert C. Upstill-Goddard ${ }^{10}$, Thomas S. Weber $^{6}$, Damian L. Arévalo-Martínez ${ }^{11}$, Hermann W. Bange ${ }^{11}$, Heather M. Benway ${ }^{12}$, Daniele Bianchi ${ }^{13}$, Alberto V. Borges ${ }^{14}$, Bonnie X. Chang ${ }^{15,16}$, Patrick M. Crill ${ }^{9}$, Daniela A. del Valle ${ }^{17}$, Laura Farías ${ }^{18}$, Samantha B. Joye ${ }^{19}$, Annette Kock ${ }^{11}$, Jabrane Labidi ${ }^{20}$, Cara C. Manning $^{21, a}$, John W. Pohlman ${ }^{22}$, Gregor Rehder ${ }^{23}$, Katy J. Sparrow ${ }^{24}$, Philippe D. Tortell ${ }^{21}$, Tina Treude ${ }^{13,20}$, David L. Valentine ${ }^{25}$, Bess B. Ward ${ }^{26}$, Simon Yang ${ }^{13}$, and Leonid N. Yurganov ${ }^{27}$

${ }^{1}$ University of Hawai'i at Manoa, Daniel K. Inouye Center for Microbial Oceanography: Research and Education (C-MORE), Honolulu, Hawai'i, USA

${ }^{2}$ Department of Earth and Environment, Boston University, Boston, Massachusetts, USA

${ }^{3}$ University of South Carolina, School of the Earth, Ocean and Environment, Columbia, South Carolina, USA

${ }^{4}$ Department of Environmental Science, University of Basel, Basel, Switzerland

${ }^{5}$ Department of Biology, Boston University, Boston, Massachusetts, USA

${ }^{6}$ Department of Earth and Environmental Science, University of Rochester, Rochester, New York, USA

${ }^{7}$ Department of Biogeochemistry, Max Planck Institute for Marine Microbiology, Bremen, Germany

${ }^{8}$ School of Environmental Sciences, University of East Anglia, Norwich, UK

${ }^{9}$ Department of Geological Sciences and Bolin Centre for Climate Research, Stockholm University, Stockholm, Sweden

${ }^{10}$ School of Natural and Environmental Sciences, Newcastle University, Newcastle upon Tyne, UK

${ }^{11}$ GEOMAR Helmholtz Centre for Ocean Research Kiel, Düsternbrooker Weg 20, 24105 Kiel, Germany

${ }^{12}$ Woods Hole Oceanographic Institution, Marine Chemistry and Geochemistry, Boston, Massachusetts, USA

${ }^{13}$ Department of Atmospheric and Oceanic Sciences, University of California Los Angeles, Los Angeles, California, USA

${ }^{14}$ University of Liège, Chemical Oceanography Unit, Liège, Belgium

${ }^{15}$ University of Washington, Joint Institute for the Study of the Atmosphere and Ocean, Seattle, Washington, USA

${ }^{16}$ National Oceanic and Atmospheric Administration, Pacific Marine Environmental Laboratory, Seattle, Washington, USA

${ }^{17}$ University of Southern Mississippi, Division of Marine Science, Hattiesburg, Mississippi, USA

${ }^{18}$ Department of Oceanography and Center for Climate Research and Resilience (CR2),

University of Concepción, Concepción, Chile

${ }^{19}$ Department of Marine Sciences, Georgia, University of Georgia, Athens, USA

${ }^{20}$ Department of Earth, Planetary, and Space Sciences, University of California Los Angeles, Los Angeles, California, USA

${ }^{21}$ Department of Earth, Ocean and Atmospheric Sciences, University of British Columbia,

British Columbia, Vancouver, Canada

${ }^{22}$ U.S. Geological Survey, Woods Hole Coastal and Marine Science Center, Woods Hole, USA

${ }^{23}$ Leibniz Institute for Baltic Sea Research Warnemünde, Rostock, Germany

${ }^{24}$ Department of Earth, Ocean, and Atmospheric Science, Florida State University, Tallahassee, Florida, USA

${ }^{25}$ Department of Earth Science, University of California Santa Barbara, Santa Barbara, California, USA

${ }^{26}$ Geoscience Department, Princeton University, Princeton, New Jersey, USA

${ }^{27}$ Joint Center for Earth Systems Technology, University of Maryland Baltimore County, Baltimore, Maryland, USA

${ }^{a}$ current address: Plymouth Marine Laboratory, Plymouth, UK

Correspondence: Samuel T. Wilson (stwilson@hawaii.edu) 
Received: 14 July 2020 - Discussion started: 23 July 2020

Revised: 10 October 2020 - Accepted: 12 October 2020 - Published: 26 November 2020

\begin{abstract}
In the current era of rapid climate change, accurate characterization of climate-relevant gas dynamics - namely production, consumption, and net emissions - is required for all biomes, especially those ecosystems most susceptible to the impact of change. Marine environments include regions that act as net sources or sinks for numerous climateactive trace gases including methane $\left(\mathrm{CH}_{4}\right)$ and nitrous oxide $\left(\mathrm{N}_{2} \mathrm{O}\right)$. The temporal and spatial distributions of $\mathrm{CH}_{4}$ and $\mathrm{N}_{2} \mathrm{O}$ are controlled by the interaction of complex biogeochemical and physical processes. To evaluate and quantify how these mechanisms affect marine $\mathrm{CH}_{4}$ and $\mathrm{N}_{2} \mathrm{O}$ cycling requires a combination of traditional scientific disciplines including oceanography, microbiology, and numerical modeling. Fundamental to these efforts is ensuring that the datasets produced by independent scientists are comparable and interoperable. Equally critical is transparent communication within the research community about the technical improvements required to increase our collective understanding of marine $\mathrm{CH}_{4}$ and $\mathrm{N}_{2} \mathrm{O}$. A workshop sponsored by Ocean Carbon and Biogeochemistry (OCB) was organized to enhance dialogue and collaborations pertaining to marine $\mathrm{CH}_{4}$ and $\mathrm{N}_{2} \mathrm{O}$. Here, we summarize the outcomes from the workshop to describe the challenges and opportunities for near-future $\mathrm{CH}_{4}$ and $\mathrm{N}_{2} \mathrm{O}$ research in the marine environment.
\end{abstract}

\section{Background}

The most abundant greenhouse gases in the troposphere, excluding water vapor, are carbon dioxide $\left(\mathrm{CO}_{2}\right)$, methane $\left(\mathrm{CH}_{4}\right)$, and nitrous oxide $\left(\mathrm{N}_{2} \mathrm{O}\right)$. Together they account for more than $80 \%$ of the total radiative forcing (IPCC, 2013), and their current tropospheric mole fractions and rates of increase are unprecedented in recent Earth history (Ciais et al., 2013; Burke et al., 2018; Fig. 1a and b). While $\mathrm{CO}_{2}$ is the most abundant of the three greenhouse gases, $\mathrm{CH}_{4}$ and $\mathrm{N}_{2} \mathrm{O}$ both have a higher warming potential than $\mathrm{CO}_{2}$ (Montzka et al., 2011). Accurately constraining the contribution of $\mathrm{CH}_{4}$ and $\mathrm{N}_{2} \mathrm{O}$ to Earth's radiation budget and their representation in predictive models requires their sources and sinks to be quantified with high resolution at the global scale.

The oceans are a fundamental component of the global climate system and are a net source of tropospheric $\mathrm{CH}_{4}$ and $\mathrm{N}_{2} \mathrm{O}$ at the global scale, although local to regional budgets may include both source and sink components. There are far fewer measurements of dissolved $\mathrm{CH}_{4}$ and $\mathrm{N}_{2} \mathrm{O}$ than of dissolved $\mathrm{CO}_{2}$ and while there is substantial international coordination with regard to $\mathrm{CO}_{2}$ analysis, calibration, and data reporting, no such coordination yet exists for $\mathrm{CH}_{4}$ and $\mathrm{N}_{2} \mathrm{O}$
(Wilson et al., 2018). Given the increasing prominence of climate change on scientific and societal agendas, greater coordination among the marine $\mathrm{CH}_{4}$ and $\mathrm{N}_{2} \mathrm{O}$ scientific community to provide more targeted measurements and increase the quality and interoperability of $\mathrm{CH}_{4}$ and $\mathrm{N}_{2} \mathrm{O}$ observations is particularly timely.

Despite the lack of an international coordinating framework, there have been important advances in our understanding of marine $\mathrm{CH}_{4}$ and $\mathrm{N}_{2} \mathrm{O}$ in numerous research disciplines, ranging from cellular metabolism and model microbial systems to large-scale modeling. For example, recent work identified novel microorganisms and metabolic pathways in the production of $\mathrm{N}_{2} \mathrm{O}$ (Trimmer et al., 2016; Caranto and Lancaster, 2017) and $\mathrm{CH}_{4}$ (Repeta et al. 2016; Bižić et al., 2020). Earth system models now incorporate improved $\mathrm{N}_{2} \mathrm{O}$ parameterizations to better resolve the ocean's role in the global $\mathrm{N}_{2} \mathrm{O}$ cycle (Battaglia and Joos, 2018). New techniques enable the discrimination of ancient and modern dissolved $\mathrm{CH}_{4}$ (Sparrow et al., 2018) and the transfer of $\mathrm{CH}_{4}$ derived carbon to other carbon pools (Pohlman et al., 2011; Garcia-Tigreros and Kessler, 2018). Other technological and analytical advances include improved near-continuous spectroscopic analysis that yields greater sampling resolution in surface waters (e.g., Gülzow et al., 2011; Arévalo-Martínez et al., 2013; Erler et al., 2015) and the deployment of analytical devices on robotic vehicles (Nicholson et al., 2018).

These scientific advances and an improvement in the quantity and quality of $\mathrm{CH}_{4}$ and $\mathrm{N}_{2} \mathrm{O}$ observations are timely given that large areas of both the open and coastal ocean remain undersampled (Fig. 1c and d). Limited observations contribute to uncertainty in marine $\mathrm{CH}_{4}$ and $\mathrm{N}_{2} \mathrm{O}$ inventories, their rates of production and consumption, and their emissions. The uncertainty associated with $\mathrm{CH}_{4}$ and $\mathrm{N}_{2} \mathrm{O}$ inventories is particularly problematic given that the marine environment is susceptible to an accelerating rate of anthropogenic change that will continue to modify the global cycles of carbon and nitrogen into the future. Environmental impacts on marine $\mathrm{CH}_{4}$ and $\mathrm{N}_{2} \mathrm{O}$ distributions include increasing seawater temperatures, decreasing concentrations of dissolved oxygen $\left(\mathrm{O}_{2}\right)$, acidification, retreat of ice and mobilization of carbon substrates from former permafrost altering coastal run-off, and eutrophication (IPCC, 2019). These impacts will undoubtedly alter future $\mathrm{CH}_{4}$ and $\mathrm{N}_{2} \mathrm{O}$ exchange with the atmosphere, but the directions and magnitudes of these modified fluxes remain insufficiently understood.

The need to resolve the marine $\mathrm{CH}_{4}$ and $\mathrm{N}_{2} \mathrm{O}$ inventories prompted an evaluation of the collective ability of the international scientific community to accurately determine the distribution and emissions of $\mathrm{CH}_{4}$ and $\mathrm{N}_{2} \mathrm{O}$ and the determining physical-biogeochemical factors. This became the 

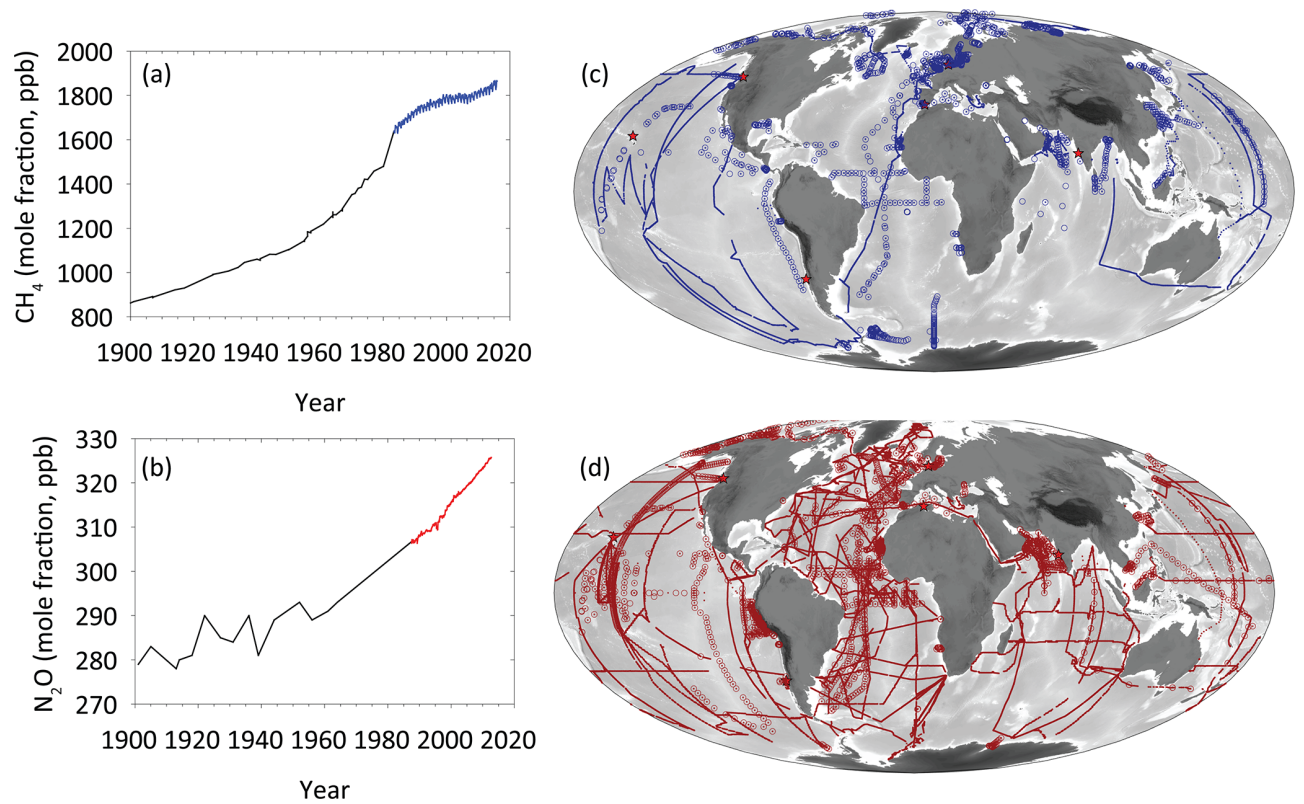

Figure 1. Atmospheric values of (a) $\mathrm{CH}_{4}$ and (b) $\mathrm{N}_{2} \mathrm{O}$ with the black lines reconstructed from ice-core measurements (Etheridge et al., 1998; Machida et al., 1995) and the colored lines from Mauna Loa Observatory (https://www.esrl.noaa.gov/gmd/dv/data/, last access: 1 July 2020). Global maps of marine (c) $\mathrm{CH}_{4}$ and (d) $\mathrm{N}_{2} \mathrm{O}$ measurements available from the MEMENTO database (https://memento.geomar.de/, last access: 1 July 2020). The 2018 workshop focused on the marine contribution to atmospheric $\mathrm{CH}_{4}$ and $\mathrm{N}_{2} \mathrm{O}$ and the underlying microbial and biogeochemical control mechanisms.

focus of a marine $\mathrm{CH}_{4}$ and $\mathrm{N}_{2} \mathrm{O}$ workshop hosted by the Ocean Carbon and Biogeochemistry (OCB) program at Lake Arrowhead, California, in October 2018. The workshop considered $\mathrm{CH}_{4}$ and $\mathrm{N}_{2} \mathrm{O}$ equally on the same agenda, even though nearly all field, laboratory, and modeling studies examine these trace gases separately. The rationale for this dual approach is that $\mathrm{CH}_{4}$ and $\mathrm{N}_{2} \mathrm{O}$ share common considerations of the physical, chemical, and microbial processes that dictate their water column distributions (Bakker et al., 2014; Bodelier and Steenbergh, 2014). In addition, many of the analytical procedures for quantifying $\mathrm{CH}_{4}$ and $\mathrm{N}_{2} \mathrm{O}$ and the subsequent data quality assurances share many common requirements. The opportunity to bring a large research community together to increase dialogue and encourage the cross-fertilization of ideas was thus considered very valuable. This article articulates the workshop outcomes framed in the context of current marine $\mathrm{CH}_{4}$ and $\mathrm{N}_{2} \mathrm{O}$ research and explores future research opportunities and challenges.

\section{Coordination of oceanic $\mathrm{CH}_{4}$ and $\mathrm{N}_{2} \mathrm{O}$ measurements}

Our understanding of the temporal and spatial distributions of oceanic $\mathrm{CH}_{4}$ and $\mathrm{N}_{2} \mathrm{O}$ derives from over 5 decades of open ocean and coastal observations, including targeted expeditions, repeat hydrographic surveys, and time-series monitoring, each of which has been crucial to the development of our current knowledge (Fig. 2). Targeted programs have enabled invaluable insights into the role of oxygen-deficient zones in $\mathrm{N}_{2} \mathrm{O}$ cycling (Babbin et al., 2015; Bourbonnais et al., 2017; Frey et al., 2020) and the exploration of $\mathrm{CH}_{4}$-rich seeps and vents (Foucher et al., 2009; Suess, 2010; Boetius and Wenzhöfer, 2013). Basin-scale repeat hydrographic surveys (e.g., the international GO-SHIP program) have facilitated extensive water column mapping to identify relevant water masses and evaluate ventilation rates (Fig. 2d) (de la Paz et al., 2017). Other oceanic surveys have focused exclusively on surface sampling, using continuous equilibrator systems connected to various gas analyzers to yield high-resolution surface concentration fields of $\mathrm{CH}_{4}$ and $\mathrm{N}_{2} \mathrm{O}$ (Gülzow et al., 2013; Erler et al., 2015; Kodovska et al., 2016; Thornton et al., 2016a; Pohlman et al., 2017). In contrast, sustained long-term timeseries measurements of $\mathrm{CH}_{4}$ and $\mathrm{N}_{2} \mathrm{O}$ at fixed monitoring stations are relatively few, but they span a range of latitudes and biogeochemical provinces (Fig. 2a and b). The timeseries observations provide the contextual background for seasonal and interannual variation that allow long-term temporal trends and episodic events to be identified and evaluated (Farías et al., 2015; Wilson et al., 2017; Ma et al., 2019). Overall, the majority of measurements enable the variability in marine $\mathrm{CH}_{4}$ and $\mathrm{N}_{2} \mathrm{O}$ to be quantified at the mesoscale or greater (i.e., from hundreds of kilometers to ocean basins), with monthly to annual resolution, but there are substantially fewer datasets at the sub-mesoscale level (i.e., $<10 \mathrm{~km}$ and hours to days) (Fig. 3). A major reason for the limited sampling at the sub-mesoscale level is that it necessitates high- 


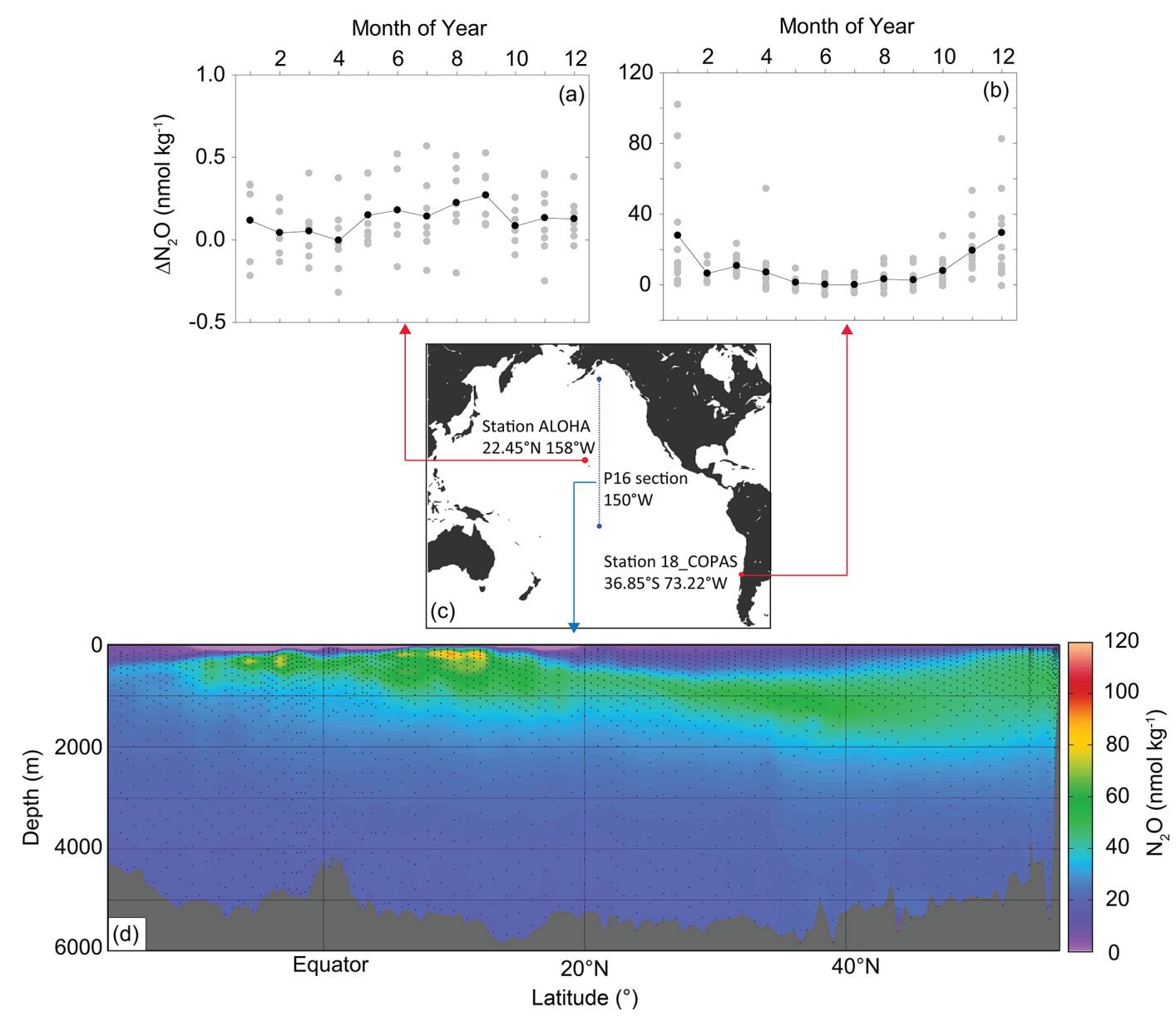

Figure 2. Highlights of repeat $\mathrm{N}_{2} \mathrm{O}$ observations in the Pacific Ocean including both (a, b) fixed-location time-series monitoring observations and (c, d) hydrographic surveys. Together, these observing programs help resolve temporal variability ranging from months to years and spatial variability at the ocean basin scale (see Fig. 3). The Station ALOHA data derive from Wilson et al. (2018), the Station 18 COPAS data derive from Farías et al. (2015), and the P16 transect was conducted in 2015 by the NOAA PMEL Ocean Tracer group as part of the GO-SHIP program. The $\mathrm{N}_{2} \mathrm{O}$ concentrations are shown as either $\Delta \mathrm{N}_{2} \mathrm{O}$ (i.e., deviation from equilibrium value) or absolute values.

resolution measurements to resolve the heterogeneous variability that exists at these time-space scales. Such analyses have only recently become technically feasible (discussed in more detail in Sect. 6).

Until recently there has been no formal coordination of observations across the $\mathrm{CH}_{4}$ and $\mathrm{N}_{2} \mathrm{O}$ scientific community. In response to this, a Scientific Committee on Oceanic Research (SCOR) Working Group was initiated in 2014 entitled "Dissolved $\mathrm{N}_{2} \mathrm{O}$ and $\mathrm{CH}_{4}$ : Working towards a global network of ocean time series measurements". A major goal of the SCOR Working Group was to unite the international community in joint activities conceived to improve and inform seagoing $\mathrm{CH}_{4}$ and $\mathrm{N}_{2} \mathrm{O}$ analyses. An important activity was the preparation and distribution of common, combined gaseous $\mathrm{CH}_{4}$ and $\mathrm{N}_{2} \mathrm{O}$ standards to 12 international laboratories, with the aim of improving and standardizing calibration (Bullister et al., 2017). A subsequent intercomparison of discrete seawater samples included the use of these standards and revealed the variability between laboratories. While there were some encouraging results from the intercomparison, such as the agreement between individual laboratories using contrasting techniques, overall a large range was observed in $\mathrm{CH}_{4}$ and $\mathrm{N}_{2} \mathrm{O}$ concentration data generated by the participating laboratories (Wilson et al., 2018). Such analytical discrepancies weaken our collective ability as a community to evaluate temporal-spatial variability in marine $\mathrm{CH}_{4}$ and $\mathrm{N}_{2} \mathrm{O}$. The discrepancies also highlighted the need for standard operating procedures (SOPs) for $\mathrm{CH}_{4}$ and $\mathrm{N}_{2} \mathrm{O}$ analyses to facilitate standardization of sampling, measurement, and calibration, as well as the reporting of data and accompanying metadata in common repositories.

A data repository for oceanic $\mathrm{CH}_{4}$ and $\mathrm{N}_{2} \mathrm{O}$ data known as the MarinE MEthane and NiTrous Oxide database (MEMENTO) was established in 2009 (Bange et al., 2009; Kock and Bange, 2015). MEMENTO is now sufficiently mature to support descriptions of the broadscale surface distributions 


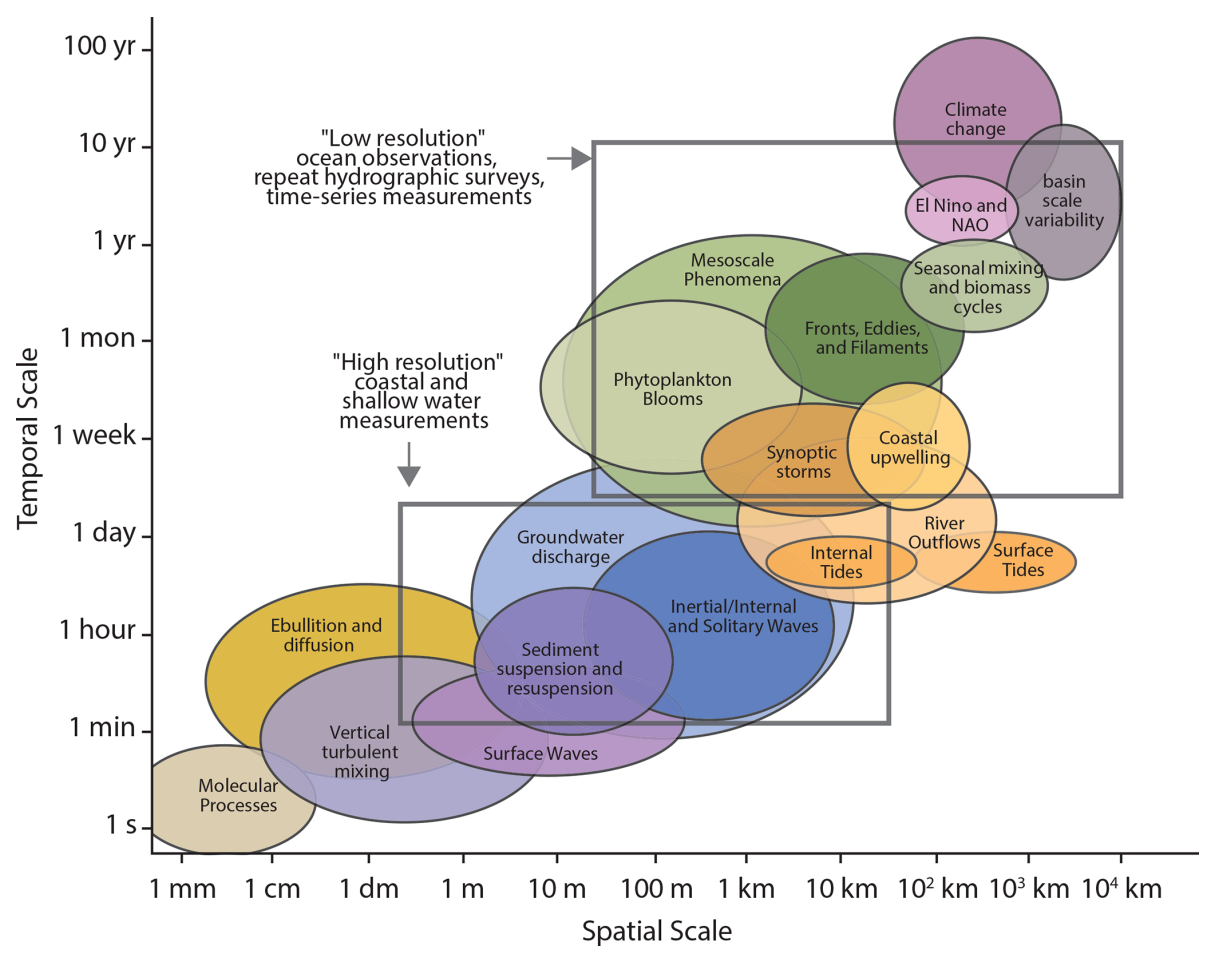

Figure 3. Time-space scale diagram illustrating various physical, biological, and climatological processes relevant to marine $\mathrm{CH}_{4}$ and $\mathrm{N}_{2} \mathrm{O}$ (adapted from Dickey, 2003). To date, the majority of marine $\mathrm{CH}_{4}$ and $\mathrm{N}_{2} \mathrm{O}$ measurements resolve variability at the mesoscale level or higher. Recent technological developments and the need to resolve concentrations and fluxes in shallow water environments will increase the number of measurements conducted at the sub-mesoscale level (see Fig. 5). The low-resolution oceanographic surveys are more likely to achieve a high level of analytical accuracy compared to high-resolution coastal measurements; however this is compensated for by high temporal resolution achieved by underway sampling.

of $\mathrm{CH}_{4}$ and $\mathrm{N}_{2} \mathrm{O}$ (e.g., Suntharalingam et al., 2012; Zamora and Oschlies, 2014; Buitenhuis et al., 2018; Battaglia and Joos, 2018). Machine-learning mapping also recently identified the various contributions of physical and biogeochemical predictor variables for $\mathrm{CH}_{4}$ (e.g., depth, primary production; Weber et al., 2019; Fig. 4b) and $\mathrm{N}_{2} \mathrm{O}$ distributions (e.g., chlorophyll, sea surface temperature, apparent oxygen utilization, and mixed-layer depth; Yang et al., 2020; Fig. 4a). The application of gas transfer algorithms to the extrapolated oceanic $\mathrm{CH}_{4}$ and $\mathrm{N}_{2} \mathrm{O}$ distributions helped decrease the uncertainty in estimates of global air-sea exchange fluxes (Fig. 4c), thereby fulfilling one of the key goals of MEMENTO (Bange et al., 2009). Net global open ocean emissions of $\mathrm{N}_{2} \mathrm{O}$ are now similarly estimated at $3-5 \mathrm{Tg} \mathrm{N} \mathrm{yr}^{-1}$ by both Yang et al. (2020) and the Global Nitrous Oxide Project (Tian et al., 2020). In comparison, net global ocean $\mathrm{CH}_{4}$ emissions from machine-learning mapping were estimated at 6-12 $\mathrm{Tg} \mathrm{CH}_{4} \mathrm{yr}^{-1}$ (Weber et al., 2019), compared to $9-22 \mathrm{Tg} \mathrm{CH}_{4} \mathrm{yr}^{-1}$ in the most up-to-date $\mathrm{CH}_{4}$ synthesis (Saunois et al., 2020). However, the narrower range for machine-learning-derived $\mathrm{CH}_{4}$ emissions retains high uncertainty in regions such as the Arctic, where emissions are highly heterogeneous and compounded by seasonal ice cover. Identifying the causes for uncertainty in high-emission regions will greatly aid future sampling campaigns, as is discussed in the following sections.

\section{Methane in marine environments}

In the surface waters of tropical and temperate oceans, a number of factors contribute to the low supersaturation of $\mathrm{CH}_{4}$ including direct aerobic production arising from the degradation of methylated sulfur compounds by phytoplankton (Klintzsch et al., 2019) and methyl phosphonate in phosphorus-depleted waters (Karl et al., 2008; Sosa et al., 2020), indirect production via grazing (Schmale et al., 2018), and abiotic photoproduction ( $\mathrm{Li}$ et al., 2020). A recent study demonstrated that $\mathrm{CH}_{4}$ production by cyanobacteria is linked to general cell metabolism and does not rely on the presence of methylated precursor compounds (Bižić et al., 2020). Deep within the ocean's pelagic interior, $\mathrm{CH}_{4}$ is weakly undersaturated, reflecting depletion via microbial oxidation (Reeburgh, 2007; Weber et al., 2019). Towards the coastline, $\mathrm{CH}_{4}$ supersaturation increases by orders of magnitude (Fig. 5b), reflecting terrestrial inputs (e.g., river and groundwater), increased organic matter loading (Borges et al., 2018), and $\mathrm{CH}_{4}$ diffusion and ebullition from shallow 
(a) Annual-mean $\Delta \mathrm{pN}_{2} \mathrm{O}$ (natm)

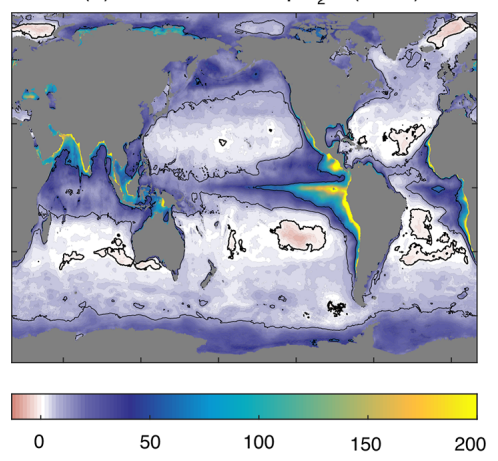

(b) Annual-mean $\triangle \mathrm{CH}_{4}(\mathrm{nM})$

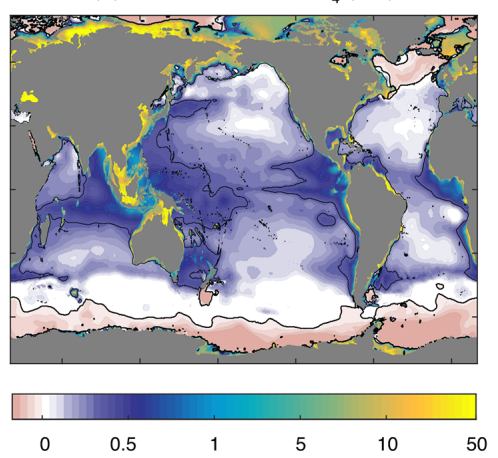

(c) Global emissions

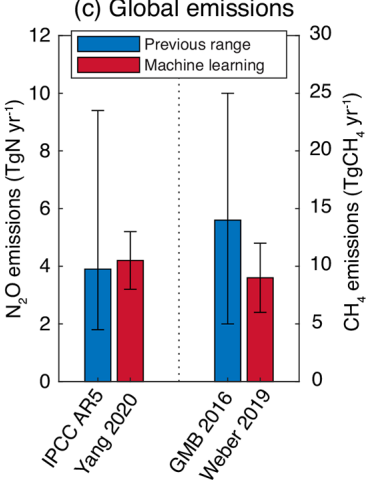

Figure 4. Distributions and emissions of marine $\mathrm{CH}_{4}$ and $\mathrm{N}_{2} \mathrm{O}$, (a) air-sea $\mathrm{N}_{2} \mathrm{O}$ disequilibrium mapped using a regression forest model (adapted from Yang et al., 2020) and (b) air-sea $\mathrm{CH}_{4}$ disequilibrium mapped using an artificial neural network model (adapted from Weber et al., 2019). For consistency with the original publications, the air-sea disequilibrium is shown in different units for $\mathrm{N}_{2} \mathrm{O}$ (partial pressure) and $\mathrm{CH}_{4}$ (concentration). (c) A summary of global ocean $\mathrm{CH}_{4}$ and $\mathrm{N}_{2} \mathrm{O}$ emissions estimated by Yang et al. (2020) and Weber et al. (2019), compared to the estimates of the IPCC 5th Annual Report (IPCC AR5) and the Global Methane Budget (Saunois et al., 2016).

anoxic methane-rich sediments (Zhang et al., 2008; Borges et al., 2016; Upstill-Goddard and Barnes, 2016). Supersaturation of $\mathrm{CH}_{4}$ occurs frequently in the Arctic Ocean and its relatively shallow marginal seas, with the most extreme values observed in the Eurasian Arctic (e.g., Shakhova et al., 2010; Damm et al., 2015; Kosmach et al., 2015; Thornton et al., 2016a; Lorenson et al., 2016; Fenwick et al., 2017; Lapham et al., 2017). Terrestrial and subsea permafrost are potential $\mathrm{CH}_{4}$ sources to shelf waters in addition to $\mathrm{CH}_{4}$ hydrates that are found in marginal shelves globally (Ruppel and Kessler, 2017). Large point source $\mathrm{CH}_{4}$ emissions, such as seafloor gas seeps, can be large sources to the atmosphere in small localized areas (e.g., Thornton et al., 2020), but these sites remain particularly difficult to parameterize in models. This reflects limited observations and a poor understanding of their spatial distributions, the driving mechanisms, and the wider context within the carbon cycle. For example, the upwelling of cold, nutrient-rich water that accompanies $\mathrm{CH}_{4}$ ascending the water column stimulates $\mathrm{CO}_{2}$ consumption by photosynthesizing phytoplankton, rendering such $\mathrm{CH}_{4}$ seeps an overall net sink for climate-forcing gases (Pohlman et al., 2017). Recent work using thermal infrared satellite retrievals indicates increased high-latitude oceanic $\mathrm{CH}_{4}$ release in late autumn, coincident with pycnocline breakdown and a deepening of the ocean mixed-layer depth, thereby bringing deep $\mathrm{CH}_{4}$ to the surface (Yurganov et al., 2019). This is especially notable in the Kara and Barents seas, but the remote observations have not yet been confirmed by surface ocean measurements which are difficult and therefore rare, except during the Arctic summer.

Seabed $\mathrm{CH}_{4}$ emissions are hypothesized to increase in a warming ocean through the decomposition of gas hydrates, the degradation of subsea permafrost under some high-latitude seas, and the increased biodegradation of sediment carbon (Romanovskii et al., 2005; Biastoch et al., 2011;
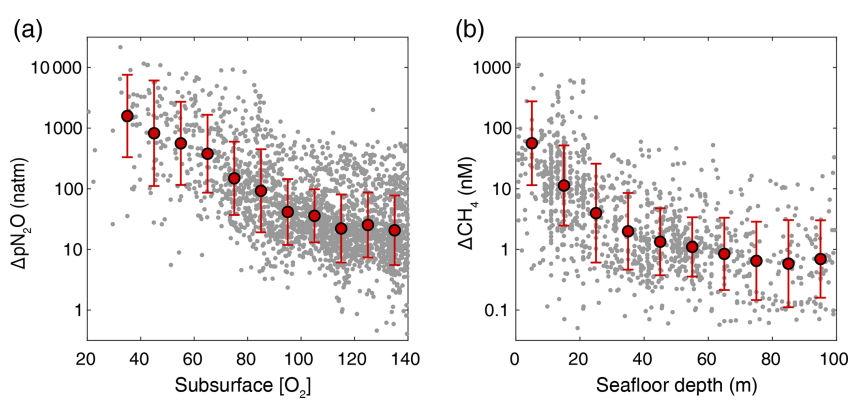

Figure 5. Key environmental predictors of surface ocean $\mathrm{CH}_{4}$ and $\mathrm{N}_{2} \mathrm{O}$ gradients. (a) Excess air-sea $\mathrm{N}_{2} \mathrm{O}$ is best predicted by $\mathrm{O}_{2}$ concentrations in the subsurface water column (base of the mixed layer to a depth of $100 \mathrm{~m}$ ) (adapted from Yang et al., 2020). (b) Excess $\mathrm{CH}_{4}$ is best predicted by seafloor depth, reflecting the supply from anoxic sediments (adapted from Weber et al., 2019). The grey dots represent individual data points and the red dots with error bars represent mean $\pm 1 \mathrm{SD}$ of binned data, using $\mathrm{O}_{2}$ bins of $10 \mu \mathrm{M}$ width and seafloor depth bins of $10 \mathrm{~m}$ width.

Lapham et al., 2013; Ruppel and Kessler, 2017; Borges et al., 2019). Effort is thus focused on quantifying the fraction of $\mathrm{CH}_{4}$ generated in or released from marine sediments that ultimately enters the atmosphere, particularly on shallow continental shelves and in coastal ecosystems. Natural stable isotopes have been used to inform spatial and temporal changes in dissolved $\mathrm{CH}_{4}$ concentrations (e.g., Pack et al., 2011; Mau et al., 2012; Weinstein et al., 2016; Leonte et al., 2017; Chan et al., 2019), and incubation experiments with added stable isotopes and radiotracers have helped elucidate how oxidation (anaerobically in sediments and aerobically in the water column), ebullition (where $\mathrm{CH}_{4}$ pore water partial pressure exceeds sediment hydrostatic pressure), and subsequent bubble dissolution in the water column interact to mitigate $\mathrm{CH}_{4}$ emissions to air (Steinle et al., 2015; Jordan 
et al., 2020). The information deriving from these various approaches is inherently different but complementary. Isotope tracer incubations provide snapshots of rates specific to the methanotrophic community and $\mathrm{CH}_{4}$ concentration at the time of sampling, whereas concentrations and isotopic gradients are used to infer in situ rates integrated over space and time. A recent study deployed a remotely operated vehicle to examine the isotopic fractionation of $\mathrm{CH}_{4}$ during bubble ascent and used this to constrain the extent of bubble dissolution (Leonte et al., 2018). This work demonstrated an experimental approach established for broadly constraining water column $\mathrm{CH}_{4}$ cycling directly from a surface research vessel.

Despite the range of analytical and experimental approaches available, determining whether the origin of the emitted $\mathrm{CH}_{4}$ is seafloor release or aerobic production in the upper water column remains problematic. To date there is no straightforward way to routinely distinguish between seafloor-derived and water-column-generated $\mathrm{CH}_{4}$ for all locations. Even so, stable carbon and hydrogen isotope measurements (i.e., $\delta^{13} \mathrm{C}_{-} \mathrm{CH}_{4}$ and $\delta^{2} \mathrm{H}-\mathrm{CH}_{4}$ ) combined with ancillary data may provide valuable source information. For example, combining these measurements with the ratio of $\mathrm{CH}_{4}$ to higher-order hydrocarbons (e.g., ethene $\left(\mathrm{C}_{2} \mathrm{H}_{4}\right)$ and ethane $\left.\left(\mathrm{C}_{2} \mathrm{H}_{6}\right)\right)$ can be used to infer, for example, whether the origin of the $\mathrm{CH}_{4}$ is thermogenic, sub-seafloor, or biogenic within the water column (Whiticar, 1999; Pohlman et al., 2009; Lan et al., 2019). Continuous shipboard measurement of $\mathrm{CH}_{4}$ isotopes in surface water (e.g., Pohlman et al., 2017) and in the atmospheric boundary layer (Pankratova et al., 2019; Berchet et al., 2020) are now possible and they have been used in combination with atmospheric inversion models to characterize and discriminate marine-emitted $\mathrm{CH}_{4}$ from other sources (Berchet et al., 2020). Application of this method to landbased monitoring stations appears promising for apportioning $\mathrm{CH}_{4}$ emissions from various marine regions and sources (Thonat et al., 2019). Additionally, in regions where aerobic $\mathrm{CH}_{4}$ oxidation is substantial, the resulting isotopic fractionation generates measurable vertical and/or horizontal seawater gradients that can also be used to identify contrasting biogenic $\mathrm{CH}_{4}$ sources (Leonte et al., 2020). However, the general overlap in isotope compositions of sediment $\mathrm{CH}_{4}$ (e.g., Thornton et al., 2016b; Sapart et al., 2017) can complicate purely isotope-based determinations of sources.

Measurements of the natural radiocarbon content of dissolved oceanic $\mathrm{CH}_{4}$, while being highly specialized and requiring substantial amounts of ship time and processing (Kessler and Reeburgh, 2005; Sparrow and Kessler, 2017), provide valuable source information because the ${ }^{14} \mathrm{C}-\mathrm{CH}_{4}$ measurements are normalized to the same $\delta^{13} \mathrm{C}$ value and are unaffected by the extent of oxidation. The bubbles sampled from hydrate and active seafloor seeps are largely devoid of radiocarbon (Pohlman et al., 2009; Kessler et al., 2008; Douglas et al., 2016). However, $\mathrm{CH}_{4}$ in sediments can also be derived from more modern or recently deposited organic material, and an exact determination of individual contributions is hard to achieve (Kessler et al., 2008; Sparrow et al., 2018). The powerful insights made by radiocarbon- $\mathrm{CH}_{4}$ investigations would be further strengthened by concurrent sampling of other analytes that offer $\mathrm{CH}_{4}$ source information, such as clumped isotopes. Isotope clumping, the co-occurrence of two or more of the less-abundant isotopes in a molecule (e.g., ${ }^{13} \mathrm{C}$ and ${ }^{2} \mathrm{H}$ or ${ }^{1} \mathrm{H}$ and ${ }^{2} \mathrm{H}$ ), provides unique information on marine $\mathrm{CH}_{4}$ sources (Stolper et al., 2014; Wang et al., 2015; Douglas et al., 2017; Young et al., 2017; Labidi et al., 2020). In this approach, the isotopic deviations in samples from their random probability distributions can give insight into formation temperature and the extent of biochemical disequilibrium. However, the sample size required for a clumped isotope analysis in the oceanic environment away from areas of seafloor emission is large and exceeds the already demanding volume requirements for ${ }^{14} \mathrm{C}$ analyses by 1-2 orders of magnitude (Douglas et al., 2017). While the requirement of large sample size and lengthy measurement time currently preclude their more widespread application, clumped isotope measurements offer future promise in refining our understanding of the processes of marine $\mathrm{CH}_{4}$ production and consumption.

\section{Nitrous oxide in marine environments}

The large-scale spatial distribution of $\mathrm{N}_{2} \mathrm{O}$ in the global ocean is reasonably well-established. The highest open ocean $\mathrm{N}_{2} \mathrm{O}$ values are in upwelling environments, where concentrations extend up to micromolar levels (Arévalo-Martínez et al., 2015) and production rates can be as high as $120 \mathrm{nM} \mathrm{d}^{-1}$ (Frey et al., 2020). The highly elevated $\mathrm{N}_{2} \mathrm{O}$ concentrations can be proximal to regions with some of the lowest recorded $\mathrm{N}_{2} \mathrm{O}$ concentrations, in the cores of $\mathrm{O}_{2}$-deficient zones. This coexistence of the highest and lowest observed $\mathrm{N}_{2} \mathrm{O}$ concentrations over vertical distances of tens of meters makes upwelling regions a focal point for $\mathrm{N}_{2} \mathrm{O}$ research, particularly since $\mathrm{O}_{2}$-deficient ocean zones are increasing in size (Stramma et al., 2011). In contrast, in the surface waters of the expansive oligotrophic ocean gyres, $\mathrm{N}_{2} \mathrm{O}$ is weakly supersaturated $(103 \%-105 \%)$ with respect to atmospheric equilibrium (Weiss et al., 1992; Wilson et al., 2017; Charpentier et al., 2010). Nitrous oxide becomes more highly saturated in the surface waters of equatorial upwelling regions due to the upward advection of $\mathrm{N}_{2} \mathrm{O}$-rich waters (ArévaloMartínez et al., 2017). For the Arctic Ocean, the data indicate low net $\mathrm{N}_{2} \mathrm{O}$ emissions, with some areas acting as net $\mathrm{N}_{2} \mathrm{O}$ sources and others as $\mathrm{N}_{2} \mathrm{O}$ sinks (Fenwick et al., 2017; Zhang et al., 2015).

Several parameters control net $\mathrm{N}_{2} \mathrm{O}$ emissions from the ocean, including temperature, salinity, dissolved $\mathrm{O}_{2}$, apparent oxygen utilization (AOU), nutrients, and microbial community abundance and composition. A recent modeling study trained with just three of these variables (chlorophyll, $\mathrm{O}_{2}$, and AOU) accounted for $60 \%$ of the observed variability 
in oceanic $\mathrm{N}_{2} \mathrm{O}$ concentrations (Yang et al., 2020; Fig. 5a), highlighting the importance of $\mathrm{N}_{2} \mathrm{O}$ in productive upwelling systems. Correlations between $\mathrm{N}_{2} \mathrm{O}$ and environmental variables provide some insight into the factors controlling its distribution, but they provide no information about the microorganisms or metabolic pathways involved. Microbial production of $\mathrm{N}_{2} \mathrm{O}$ occurs during the metabolic processes of nitrification and denitrification (Stein and Yung, 2003). To determine which process dominates $\mathrm{N}_{2} \mathrm{O}$ production at any given location requires the application of multiple methodological approaches, ideally in parallel.

One of the most commonly used approaches is the incubation of discrete water samples under in situ conditions with stable isotope $\left({ }^{15} \mathrm{~N}\right)$ addition such as ${ }^{15} \mathrm{~N}$-enriched $\mathrm{NH}_{4}^{+}$, $\mathrm{NO}_{2}^{-}$, or $\mathrm{NO}_{3}^{-}$to measure $\mathrm{N}_{2} \mathrm{O}$ production rates from nitrification and denitrification (e.g., Ji et al., 2017). These approaches also provide insight into the microorganisms involved. For example, $\mathrm{N}_{2} \mathrm{O}$ resulting from archaeal $\mathrm{NH}_{4}^{+}$oxidation is mostly formed from a combination of $\mathrm{NH}_{4}^{+}$and another $\mathrm{N}$ compound (e.g., $\mathrm{NO}_{2}^{-}$) whereas bacteria produce $\mathrm{N}_{2} \mathrm{O}$ from $\mathrm{NH}_{4}^{+}$alone (Santoro et al., 2011; Stieglmeier et al., 2014; Carini et al., 2018; Lancaster et al., 2018; Frey et al., 2020). Unfortunately, as with all incubation-based approaches ${ }^{15} \mathrm{~N}$ techniques are subject to bottle artifacts, and the strong dependence of $\mathrm{N}_{2} \mathrm{O}$ production and consumption on ambient $\mathrm{O}_{2}$ increases the potential for contamination during the collection and manipulation of anoxic deep seawaters. Incubation-based rate measurements are also compromised by abiotic $\mathrm{N}_{2} \mathrm{O}$ production via chemodenitrification, specifically the reduction of $\mathrm{NO}_{2}^{-}$coupled to $\mathrm{Fe}^{2+}$ oxidation, as observed in high-Fe environments (Ostrom et al., 2016; Buchwald et al., 2016; Wankel et al., 2017). These issues highlight the need for incubation techniques that mitigate the effect of experimental artifacts (Stewart et al., 2012).

In addition to isotope addition and incubation, natural abundance water column measurements of $\mathrm{N}_{2} \mathrm{O}$ concentrations, isotopes, and isotopomers yield valuable rate and process information. These measurements are free from experimental artifacts and can be used to integrate over appropriate temporal and spatial scales. For example, nitrification in sunlit waters has been inferred from $\mathrm{N}_{2} \mathrm{O}$ distributions (Dore and Karl, 1996), and $\mathrm{N}_{2} \mathrm{O}$ production close to the ocean surface is a large contributor to the uncertainty in oceanic $\mathrm{N}_{2} \mathrm{O}$ emissions (Ward et al., 1982; Zamora and Oeschlies, 2014). Isotopomers are isomers having the same number of each isotope of each element but differing in their structural positions. Nitrous oxide isotopomers are increasingly used, sometimes in combination with box models, to estimate the rates of different $\mathrm{N}_{2} \mathrm{O}$ production pathways, in the upwelling systems off southern Africa (Frame et al., 2014) and Peru (Bourbonnais et al., 2017). There is however some disagreement about whether isotopomer signatures are robust indicators of the formation pathway (Yoshida and Toyoda, 2000; Sutka et al., 2006) or whether there is fractionation during production (Schmidt et al., 2004; Casciotti et al., 2018). Greater clarity is therefore required in the use of $\mathrm{N}_{2} \mathrm{O}$ isotopes and isotopomers to infer metabolic pathways of $\mathrm{N}_{2} \mathrm{O}$ formation. Notwithstanding this issue, field measurements of $\mathrm{N}_{2} \mathrm{O}$ isotopes and/or isotopomers have the potential to greatly increase current experimental capabilities and robustness (Yu et al., 2020). However, the development of spectroscopic gas analysis systems that have been so advantageous to $\mathrm{CH}_{4}$ research has been slower for $\mathrm{N}_{2} \mathrm{O}$. This is due to the higher costs and the increased complexity of the laser systems, although progress is being made to improve instrumental precision and to decrease matrix effects and spectral interferences (e.g., Harris et al., 2019).

A better understanding of the microorganisms responsible for $\mathrm{N}_{2} \mathrm{O}$ production and consumption is fundamental to deriving more accurate estimates of process rates. For example, the metabolic activity of ammonia-oxidizing archaea can exceed that of ammonia-oxidizing bacteria in the ocean (Santoro et al., 2010; Löscher et al., 2012; Fuchsman et al., 2017). The differing sensitivities of these archaea and bacteria to dissolved $\mathrm{O}_{2}$ (Stahl and de la Torre, 2012; Hink et al., 2017) are a critical factor in evaluating the microbial response to changing environmental conditions, as shown for the terrestrial environment (Prosser at al., 2020). Therefore, to understand the impact of deoxygenation on oceanic $\mathrm{N}_{2} \mathrm{O}$ emission requires a better understanding of both archaeal and bacterial metabolisms and their environmental niches. Fieldbased sequencing not only characterizes the community but can also highlight potential metabolic pathways when they might not otherwise be inferred. For example, transcripts encoding for $\mathrm{N}_{2} \mathrm{O}$ consumption (nosZ) have repeatedly been identified in the oxic water column, despite denitrification being an anaerobic metabolic process (Wyman et al., 2013; Sun et al., 2017). The transcription of nosZ has also been located in highly dynamic $\mathrm{O}_{2}$ permeable coastal sediments (Marchant et al., 2017). Denitrification under aerobic conditions is attributed to fluctuations in $\mathrm{O}_{2}, \mathrm{NO}_{3}^{-}$, organic matter, and other parameters that affect the availability of electron donors and acceptors, which ultimately influences whether a coastal environment is a net source or sink of $\mathrm{N}_{2} \mathrm{O}$, as discussed in the next section.

\section{$5 \mathrm{CH}_{4}$ and $\mathrm{N}_{2} \mathrm{O}$ in shallow marine environments}

Coastal and other shallow $(<50 \mathrm{~m})$ marine systems are globally relevant $\mathrm{CH}_{4}$ and $\mathrm{N}_{2} \mathrm{O}$ source regions. However, their emission rates to the atmosphere are weakly constrained in comparison with the open ocean. Several factors contribute to the uncertainty, including the high diversity of coastal and shallow marine ecosystems and lack of consistency in adequately defining them, locally heterogeneous conditions causing strong spatial and temporal concentration gradients, highly uncertain spatial distribution of $\mathrm{CH}_{4}$ seeps, a bias towards studies in the Northern Hemisphere, and incomplete or sometimes inappropriate sampling strategies (Al-Haj 
and Fulweiler, 2020). Until these issues are resolved it will remain difficult to adequately define the contribution from shallow marine systems to global $\mathrm{CH}_{4}$ and $\mathrm{N}_{2} \mathrm{O}$ budgets. An important illustration of this is reflected in the prevailing view that large geological sources (e.g., seeps, mud volcanoes, and hydrates) are the main contributors to marine $\mathrm{CH}_{4}$ emissions (Ciais et al., 2013). The most recent modeled estimate of global marine $\mathrm{CH}_{4}$ emissions $\left(6-12 \mathrm{Tg} \mathrm{CH}_{4} \mathrm{yr}^{-1}\right)$ reported that nearshore environments (depths of $0-50 \mathrm{~m}$ ) contribute a large and highly uncertain diffusive flux (Weber et al., 2019). A study of coastal ecosystems, in this case defined as shelf, estuarine, and tidally influenced rivers, estimated them to contribute $7 \mathrm{Tg} \mathrm{CH}_{4} \mathrm{yr}^{-1}$ (Anderson et al., 2010) while another estimated $1-7 \mathrm{Tg} \mathrm{CH}_{4} \mathrm{yr}^{-1}$ for estuaries alone (Borges and Abril, 2011). Similar uncertainties exist for $\mathrm{N}_{2} \mathrm{O}$. Estimates of coastal $\mathrm{N}_{2} \mathrm{O}$ emissions (which include coastal, estuarine, and riverine sources) range from 0.1 to $2.9 \mathrm{Tg} \mathrm{Nyr}^{-1}$ (Ciais et al., 2013), although a recent review of $\mathrm{N}_{2} \mathrm{O}$ production across a range of estuarine habitats placed $\mathrm{N}_{2} \mathrm{O}$ fluxes at the lower end of these estimates $(0.17-$ $0.95 \mathrm{Tg} \mathrm{N} \mathrm{yr}^{-1}$ ) (Murray et al., 2015). Based on these data, coastal systems account for around one-third of total marine $\mathrm{N}_{2} \mathrm{O}$ emissions (Yang et al., 2020).

The direct quantification of $\mathrm{CH}_{4}$ and $\mathrm{N}_{2} \mathrm{O}$ emissions from shallow coastal ecosystems has historically involved using gas concentrations measured in discrete water and air samples combined with a gas transfer velocity $\left(k_{\mathrm{w}}\right)$. For the coastal and open ocean, the dominant driver of gas exchange is wind speed (e.g., Nightingale et al., 2000; Wanninkhof, 2014) whereas in nearshore, shallow water environments the interaction of water, depth, and tidal current speeds may be a major contributor to near-surface turbulence. Several $k_{\mathrm{w}}$ parameterizations are now in use for coastal waters (e.g., Raymond and Cole, 2001; Kremer et al., 2003; Zappa et al., 2003; Borges and Abril, 2011; Ho et al. 2011; Rosentreter et al., 2017; Jeffrey et al., 2018), which increases the uncertainties associated with $\mathrm{CH}_{4}$ and $\mathrm{N}_{2} \mathrm{O}$ emissions. For example, a 5-fold variation in $\mathrm{CH}_{4}$ emissions from a single system occurred when applying different parameterizations to the measured gradients in $\mathrm{CH}_{4}$ (Ferrón et al., 2007).

To constrain emissions over small areas, continuous airsea fluxes can be measured using free-floating chambers (e.g., Bahlmann et al., 2015; Rosentreter et al., 2018; Yang et al., 2018; Murray et al., 2020), but issues related to turbulence modification may still generate flux artifacts (UpstillGoddard, 2006). To overcome these problems in the future, a greater reliance on direct and robust continuous techniques for air-sea flux measurement, such as eddy covariance (e.g., Podgrajsek et al., 2016), that avoid any need for $k_{\mathrm{w}}$ will be necessary. Eddy-covariance measurements also capture both diffusive and ebullitive flux components (Thornton et al., 2020). Combining this approach with new analytical techniques such as cavity enhanced absorption spectroscopy (CEAS) and non-dispersive infrared (NDIR) spectroscopy should continue to improve the quality of $\mathrm{CH}_{4}$ and $\mathrm{N}_{2} \mathrm{O}$ flux estimates (McDermitt et al., 2011; Nemitz et al., 2018; Maher et al., 2019). Indeed, eddy flux towers aboard ships (Thornton et al., 2020) and in coastal locations (Yang et al., 2016; Gutiérrez-Loza et al., 2019) are now being equipped with $\mathrm{CH}_{4}$ instrumentation that enables the integration of $\mathrm{CH}_{4}$ fluxes over large areas. There are fewer $\mathrm{N}_{2} \mathrm{O}$ flux estimates made with CEAS and NDIR, and the implementation of $\mathrm{N}_{2} \mathrm{O}$ sensors on eddy flux towers remains limited. Recently, $\mathrm{N}_{2} \mathrm{O}$ emissions from eastern-boundary upwelling systems were quantified using inversion modeling based on atmospheric measurements from coastal monitoring stations, highlighting the potential of this approach to constrain $\mathrm{N}_{2} \mathrm{O}$ emissions from remote oceanographic regions that have significant spatial and temporal heterogeneity (Ganesan et al., 2020; Babbin et al., 2020). Inverse modeling of atmospheric measurements was also recently used to constrain $\mathrm{CH}_{4}$ emissions from the East Siberian Arctic Shelf (Tohjima et al., 2020).

Coastal measurements of $\mathrm{CH}_{4}$ and $\mathrm{N}_{2} \mathrm{O}$ also require the collection of ancillary data such as water column depth, tidal motions (Rosentreter et al., 2018; Huang et al., 2019; Pfeiffer-Hebert et al., 2019), and other information relating to diel processes (Maher et al., 2016). Such data are important because for example, the magnitude of $\mathrm{CH}_{4}$ and $\mathrm{N}_{2} \mathrm{O}$ fluxes varies over a diel period depending on the redox environment as a result of tidal effects and changes in inorganic $\mathrm{N}$ and $\mathrm{O}_{2}$ availability (Seitzinger and Kroeze, 1998; Call et al., 2015; Vieillard and Fulweiler, 2014; Maher et al., 2015; Murray et al., 2015; Foster and Fulweiler, 2019). The magnitude of $\mathrm{CH}_{4}$ and $\mathrm{N}_{2} \mathrm{O}$ fluxes also varies over longer temporal scales (seasonally to yearly) due to additional factors such as groundwater inputs, adjacent land use, dissolved $\mathrm{O}_{2}$, organic matter content and quality, and macrofaunal distributions (Barnes and Upstill-Goddard, 2011; Upstill-Goddard and Barnes, 2016; Gelesh et al., 2016; Bonaglia et al., 2017; Borges et al., 2018; Wells et al., 2018; Ray et al., 2019; AlHaj and Fulweiler, 2020; Reading et al., 2020). To determine the contributing factors and resolve the spatial distributions, mobile sampling platforms such as small vessels (Müller et al., 2016; Brase et al., 2017; Tait et al., 2017) and autonomous vehicles (Manning et al., 2019) are essential. Recent improvements in gas sensors and in technology such as sonar and ebullition sensors will further increase our ability to measure dynamic fluxes (Maher et al., 2019; Lohrberg et al., 2020). Improvements to the quality and quantity of $\mathrm{CH}_{4}$ and $\mathrm{N}_{2} \mathrm{O}$ measurements in coastal systems will enable the development of iterative forecast models, further improving estimates of global coastal $\mathrm{CH}_{4}$ and $\mathrm{N}_{2} \mathrm{O}$ fluxes.

\section{Leveraging culture studies to further our ecosystem understanding}

A more complete understanding of marine $\mathrm{CH}_{4}$ and $\mathrm{N}_{2} \mathrm{O}$ necessitates closer integration between biogeochemistry, model requirements, and targeted microbiological studies involving 
both single microorganism isolates and enrichment cultures. Marine $\mathrm{CH}_{4}$ and $\mathrm{N}_{2} \mathrm{O}$ budgets deriving from both "bottomup" (e.g., emissions inventories, ocean and terrestrial process models) and "top-down" (e.g., inverse analyses of atmospheric trace-gas measurements) approaches would greatly benefit from more highly constrained metabolic processes. Specifically, this includes rates of $\mathrm{CH}_{4}$ or $\mathrm{N}_{2} \mathrm{O}$ production and consumption for key model microorganisms and the kinetic parameters associated with these metabolic rates. Reliable inventories of key microbially mediated process rates will improve the robustness of Earth system models used for predicting climate-mediated changes to marine $\mathrm{CH}_{4}$ and $\mathrm{N}_{2} \mathrm{O}$ emissions.

For $\mathrm{N}_{2} \mathrm{O}$, laboratory studies quantifying microbial process rates, such as for nitrification and denitrification, are relatively few (e.g., Frame and Casciotti, 2010; Santoro et al., 2011; Löscher et al., 2012; Ji et al., 2015; Qin et al., 2017). Consequently, models largely continue to use process rates optimized using water column concentrations of $\mathrm{N}_{2} \mathrm{O}, \mathrm{O}_{2}$, and related nitrogen cycle quantities (e.g., Battaglia and Joos, 2018; Buitenhuis et al., 2018; Landolfi et al., 2017). Future model parameterizations for $\mathrm{N}_{2} \mathrm{O}$ will require information on the variability of microbial process yields derived from culture studies with controlled varying conditions of $\mathrm{O}_{2}$ (Goreau et al., 1980; Frame and Casciotti, 2010; Löscher et al., 2012; Ji et al., 2018), pH (Breider et al., 2019; Hopkins et al., 2020), temperature, and nutrients. Automated incubation systems have measured $\mathrm{N}_{2} \mathrm{O}$ production kinetics and yield as functions of the concentrations of $\mathrm{O}_{2}$ and total ammonia nitrogen (Molstad et al., 2007; Hink et al., 2017). Quantifying the physiology of relevant microorganisms and connecting them to environmental characteristics will provide insights into why, for example, some shallow marine habitats act as $\mathrm{N}_{2} \mathrm{O}$ sinks while others are $\mathrm{N}_{2} \mathrm{O}$ sources or how $\mathrm{N}_{2} \mathrm{O}$ is produced in well-oxygenated open ocean waters, compared to oxygen-deficient zones.

For $\mathrm{CH}_{4}$, a key requirement to relate in situ $\mathrm{CH}_{4}$ production with transport to atmospheric emissions is our ability to accurately determine rates of $\mathrm{CH}_{4}$ oxidation. Fundamental issues include the challenges of cultivating methanotrophs and of replicating environmental conditions such as pressure and the chemistry of $\mathrm{CH}_{4}$ gas bubbles. The increased emphasis on $\mathrm{CH}_{4}$ dynamics in shallow water environments highlighted in Sect. 5 must be supported by culture-based measurements of $\mathrm{CH}_{4}$ oxidation that control for temperature, $\mathrm{O}_{2}$, and other important variables. In comparison to $\mathrm{CH}_{4}$ oxidation, culture-based studies are used increasingly to identify organisms capable of aerobic $\mathrm{CH}_{4}$ production and their underlying metabolic pathways (Carini et al., 2014; Klintzsch et al; 2019; Bižić et al., 2020).

Specific cellular yields and consumption rates of $\mathrm{CH}_{4}$ and $\mathrm{N}_{2} \mathrm{O}$ are not the sole objective of culturing experiments. Cultivation of microorganisms involved in $\mathrm{CH}_{4}$ and $\mathrm{N}_{2} \mathrm{O}$ production and consumption provides vital information about the physiology, metabolism, and interactions of environ- mentally relevant clades. When combined with genomic approaches, insights can therefore be gained into the diversity and global distribution of organisms involved in $\mathrm{CH}_{4}$ and $\mathrm{N}_{2} \mathrm{O}$ cycling. For $\mathrm{CH}_{4}$ some unexpected physiologies have been revealed (Ettwig et al., 2010; Haroon et al., 2013; Ettwig et al., 2016), which has directed research into sources and sinks of $\mathrm{CH}_{4}$ in the natural environment. Similarly, our understanding of how and when ammonia oxidizers produce $\mathrm{N}_{2} \mathrm{O}$ has been facilitated by studies of cultured nitrifiers and detailed analysis of their biochemistry (Stahl and de la Torre, 2012; Caranto and Lancaster, 2017). Recent combinations of cultivation studies with environmental genomics, albeit largely for terrestrial systems, have revealed a variety of denitrifiers, many of which are only involved in specific denitrification steps (Ganesh et al., 2014; Lycus et al., 2017; Hallin et al., 2018; Marchant et al., 2018; Conthe et al., 2019).

\section{Outlook and priorities for marine $\mathrm{CH}_{4}$ and $\mathrm{N}_{2} \mathrm{O}$ measurements}

This article has assessed the collective ability of the scientific community to determine the spatial variability of marine $\mathrm{CH}_{4}$ and $\mathrm{N}_{2} \mathrm{O}$ distributions, the underlying mechanisms that determine this variability, and the resulting sea-to-air emissions. Shallow marine environments and oxygen-deficient zones are widely recognized as deserving of greater attention because they have high $\mathrm{CH}_{4}$ and $\mathrm{N}_{2} \mathrm{O}$ concentrations with inherently high uncertainties that complicate any assessment of their emissions to air (Bange et al., 1994, 1996; Bakker et al., 2014; James et al., 2016; Borges et al., 2016; Tian et al., 2020). Fortunately, recent technological advances that have increased our ability to conduct high-resolution measurements allow an optimistic outlook for making substantial progress in quantifying the $\mathrm{CH}_{4}$ and $\mathrm{N}_{2} \mathrm{O}$ budgets of these ecosystems. Even so, the inherent complexity of shallow marine environments clearly warrants a strategically coordinated approach to optimize the value of future studies. Issues to consider include identifying the locations of complementary sampling sites, standardizing sampling strategies and techniques, and agreeing on the use of common ancillary measurements that set the broad biogeochemical context (Bange et al., 2019). In contrast to the open ocean, measurement campaigns in shallow water environments are amenable to the use of eddy covariance flux towers, and they have the potential to lever resources from existing observation networks, which in North America include the Long-Term Ecological Research (LTER) network and the National Estuarine Research Reserve (NERR) System (Novick et al., 2018). Indeed, such activities are already underway; an increasing number of flux towers are being equipped for $\mathrm{CH}_{4}$ measurements (Torn et al., 2019) and future efforts should focus on the inclusion of $\mathrm{N}_{2} \mathrm{O}$ (see Sect. 5). 
We are encouraged that the Global Carbon Project with its objective of developing a complete picture of the global carbon cycle including interactions and feedbacks has expanded to include $\mathrm{CH}_{4}$ (Saunois et al., 2020) and is now incorporating $\mathrm{N}_{2} \mathrm{O}$ (Tian et al., 2020). These projects compile the most recent data from peer-reviewed analyses of the sources and sinks of atmospheric $\mathrm{CH}_{4}$ and $\mathrm{N}_{2} \mathrm{O}$ from both natural and human activities. For example, the aquatic components of the recent Global Carbon Project $\mathrm{N}_{2} \mathrm{O}$ budget reported emissions from the open ocean, inland waters, estuaries, and coastal zones. Low-oxygen oceanic regions associated with easternboundary upwelling zones and the coastal ocean were identified as key regions with significant $\mathrm{N}_{2} \mathrm{O}$ variability requiring more detailed assessment via measurement campaigns and model analyses (Tian et al., 2020). Contribution to the Global Carbon Project and similar initiatives will identify areas of synergistic $\mathrm{CH}_{4}$ and $\mathrm{N}_{2} \mathrm{O}$ research for oceanographers and other Earth observation scientists (Ganesan et al., 2019). Furthermore, as highlighted in Sect. 6, field observations alone are insufficient to improve the robustness of Earth system models, and leveraging laboratory-based microbial process studies is highly recommended.

The success of any coordinated $\mathrm{CH}_{4}$ and $\mathrm{N}_{2} \mathrm{O}$ research program relies heavily on having uniformly high confidence in the various resulting datasets and their interoperability, and we identify three key initiatives that are paramount to ensuring this.

i. The first is to develop and adopt standard operating procedures (SOPs) to help obtain intercomparable $\mathrm{CH}_{4}$ and $\mathrm{N}_{2} \mathrm{O}$ datasets of the highest possible accuracy and precision. Currently, there is no consensus definition of highquality $\mathrm{CH}_{4}$ and $\mathrm{N}_{2} \mathrm{O}$ measurements. However, an analytical agreement of $\leq 1 \%$ is considered achievable for the laboratories conducting repeat oceanographic surveys and time-series observations (Fig. 3). For context, an analytical agreement of $\leq 1 \%$ would permit the ocean's response to the increasing tropospheric $\mathrm{CH}_{4}$ and $\mathrm{N}_{2} \mathrm{O}$ mole fractions to be resolved on timescales of 10 and 5 years, respectively. These values are based on the changes in surface ocean $\mathrm{CH}_{4}$ and $\mathrm{N}_{2} \mathrm{O}$ concentrations that are predicted to occur due to the ongoing increase in tropospheric $\mathrm{CH}_{4}$ and $\mathrm{N}_{2} \mathrm{O}$ mole fractions at a seawater temperature of $20^{\circ} \mathrm{C}$ and a salinity of $35 \mathrm{~g} \mathrm{~kg}^{-1}$ and assuming all sources and sinks remaining constant. In our recent marine $\mathrm{CH}_{4}$ and $\mathrm{N}_{2} \mathrm{O}$ intercomparison exercise it was concluded that the diversity of analytical procedures employed by the participants was a major cause of high variability between the reported concentrations, highlighting an urgent requirement for $\mathrm{CH}_{4}$ and $\mathrm{N}_{2} \mathrm{O}$ SOPs (Wilson et al., 2018). Consequently, these SOPs are now being compiled by the scientific community.

ii. The second is increased regularity of intercomparison exercises through the periodic distribution of consen- sus material, i.e., water samples in which $\mathrm{CH}_{4}$ and $\mathrm{N}_{2} \mathrm{O}$ concentrations are known with high confidence, obtained by pooling analyses from several laboratories with demonstrated analytical capability. These will help the scientific community to monitor data comparability and accuracy, particularly in the case of highly elevated concentrations of $\mathrm{CH}_{4}$ and $\mathrm{N}_{2} \mathrm{O}$, i.e., those exceeding atmospheric equilibrium concentrations by at least an order of magnitude.

iii. The third activity calls for the production of global data products for dissolved $\mathrm{CH}_{4}$ and $\mathrm{N}_{2} \mathrm{O}$ measurements. To date, the MEMENTO database has been very successful at compiling $\mathrm{CH}_{4}$ and $\mathrm{N}_{2} \mathrm{O}$ datasets and making them readily accessible to the modeling community. However, the MEMENTO database has not yet yielded a global data product that includes publicly accessible quality-controlled dissolved $\mathrm{CH}_{4}$ and $\mathrm{N}_{2} \mathrm{O}$ datasets. The international marine carbon science community has widely embraced such an approach for $\mathrm{fCO}_{2}$, by submitting data to the Surface Ocean $\mathrm{CO}_{2}$ Atlas (SOCAT), which was initiated in response to the need for a quality-controlled, publicly available, global surface $\mathrm{CO}_{2}$ dataset (e.g., Bakker et al., 2016). Due to fewer measurements, a similar data product for marine $\mathrm{CH}_{4}$ and $\mathrm{N}_{2} \mathrm{O}$ would be needed every $\sim 5$ years. We consider the production of global data products for dissolved $\mathrm{CH}_{4}$ and $\mathrm{N}_{2} \mathrm{O}$ to be essential for supporting future global modeling efforts and to enhance field observations.

The benefits of pursuing the three activities described above have already been clearly demonstrated for carbon system measurements in the ocean. The intercomparability and high accuracy and precision of carbon system measurements were achieved by streamlining methodological approaches, universally adopting agreed-upon SOPs, production of reference material, and following community-driven quality control procedures (Dickson et al., 2007; Dickson et al., 2010). It is encouraging to see the marine $\mathrm{CH}_{4}$ and $\mathrm{N}_{2} \mathrm{O}$ community beginning to move in a similar direction.

Data availability. The atmospheric concentrations of $\mathrm{CH}_{4}$ and $\mathrm{N}_{2} \mathrm{O}$ in Fig. 1 originated from the Mauna Loa Observatory (NOAA Earth System Research Laboratory). The discrete monthly averaged values are publicly available online at https://www.esrl. noaa.gov/gmd/dv/data/ (NOAA Earth System Research Laboratory, 2020). The $\mathrm{N}_{2} \mathrm{O}$ concentrations shown in Fig. 2 are available from three separate data repositories: BCO-DMO (Fig. 2a), PANGAEA (Fig. 2b), and GO-SHIP (Fig. 2d). The global reconstructed climatologies of $\mathrm{CH}_{4}$ and $\mathrm{N}_{2} \mathrm{O}$ shown in Figs. 4 and 5 are adapted from Weber et al. (2019) and Yang et al. (2020). The original publications contain the specific methodologies and code, with the $\mathrm{CH}_{4}$ and $\mathrm{N}_{2} \mathrm{O}$ datasets sourced from the MEMENTO database (https://memento.geomar.de/, last access: 1 August 2020). 
Video supplement. A video supplement "Oceanic Methane and Nitrous Oxide" is attached to this publication (Hofman, 2019). The video contains conversations with participants of the 2018 OCB workshop about future research on oceanic methane and nitrous oxide. The video was commissioned by Samuel T. Wilson, produced by Thom Hoffman (producerthom@gmail.com; http://www. thomhoffman.co.uk, last access: 20 November 2020), and funded by the Moore Foundation. The video is made publicly available via the German National Library of Science and Technology (TIB) with the DOI https://doi.org/10.5446/50062 and also can be found at https:// www.youtube.com/watch?v=0DyMyIVs4Qs\&t=266s (last access: 20 November 2020).

Author contributions. The initial draft of the paper was prepared by STW, ANA, AB, CF, RWF, JDK, HKM, JM, NER, PS, BFT, RCU-G, and TSW. All coauthors contributed to the revisions and preparation of the submitted manuscript.

Competing interests. The authors declare that they have no conflict of interest.

Acknowledgements. The workshop was held at the University of California Los Angeles Lake Arrowhead conference center on 2831 October 2018 (https://web.whoi.edu/methane-workshop/, last access: 1 November 2020). We are grateful to all the participants who made valuable scientific contributions to the workshop and we thank S. Ferrón for critical comments on the manuscript. This is JISAO contribution number 2020-1080 and PMEL contribution number 5126. Any use of trade, firm, or product names is for descriptive purposes only and does not imply endorsement by the U.S. Government.

Financial support. This article was an outcome of a workshop organized by the Ocean Carbon and Biogeochemistry (OCB) project office, which is supported by the US National Science Foundation (grant no. 1558412) and the National Aeronautics and Space Administration (grant no. NNX17AB17G). The workshop received additional funding from the Scientific Committee on Ocean Research (SCOR) which receives funding from the US National Science Foundation (grant no. 1840868) and contributions by additional national SCOR committees. The Chilean COPAS $\mathrm{N}_{2} \mathrm{O}$ timeseries measurements were supported by Agencia Nacional de Investigación y Desarrollo (grant no. 1200861).

Review statement. This paper was edited by Jack Middelburg and reviewed by three anonymous referees.

\section{References}

Al-Haj, A. N. and Fulweiler, R. W.: A synthesis of methane emissions from shallow vegetated coastal ecosystems, Glob. Change Biol., 26, 2988-3005, https://doi.org/10.1111/gcb.15046, 2020.
Anderson, B., Bartlett, K., Frolking, S., Hayhoe, K., Jenkins, J., and Salas, W.: Methane and nitrous oxide emissions from natural sources, Office of Atmospheric Programs, US EPA, EPA 430-R10-001, Washington DC, USA, 2010.

Arévalo-Martínez, D. L., Beyer, M., Krumbholz, M., Piller, I., Kock, A., Steinhoff, T., Körtzinger, A., and Bange, H. W.: A new method for continuous measurements of oceanic and atmospheric $\mathrm{N}_{2} \mathrm{O}$, $\mathrm{CO}$ and $\mathrm{CO}_{2}$ : performance of off-axis integrated cavity output spectroscopy (OA-ICOS) coupled to nondispersive infrared detection (NDIR), Ocean Sci., 9, 1071-1087, https://doi.org/10.5194/os-9-1071-2013, 2013.

Arevalo-Martínez, D. L., Kock, A., Löscher, C. R., Schmitz, R. A., and Bange, H. W.: Massive nitrous oxide emissions from the tropical South Pacific Ocean, Nat. Geosci., 8, 530, https://doi.org/10.1038/ngeo2469, 2015.

Arévalo-Martínez, D. L., Kock, A., Steinhoff, T., Brandt, P., Dengler, M., Fischer, T., Körtzinger, A., and Bange, H. W.: Nitrous oxide during the onset of the Atlantic cold tongue, J. Geophys. Res.: Oceans, 122, 171-184, 2017.

Babbin, A. R., Bianchi, D., Jayakumar, A., and Ward, B. B.: Rapid nitrous oxide cycling in the suboxic ocean, Science, 348, 11271129, 2015.

Babbin, A. R., Boles, E. L., Mühle, J., and Weiss, R. F.: On the natural spatio-temporal heterogeneity of South Pacific nitrous oxide, Nat. Commun., 11, 1-9, 2020.

Bahlmann, E., Weinberg, I., Lavrič, J. V., Eckhardt, T., Michaelis, W., Santos, R., and Seifert, R.: Tidal controls on trace gas dynamics in a seagrass meadow of the Ria Formosa lagoon (southern Portugal), Biogeosciences, 12, 1683-1696, https://doi.org/10.5194/bg-12-1683-2015, 2015.

Bakker, D. C. E., Bange, H. W., Gruber, N., Johannessen, T., Upstill-Goddard, R. C., Borges, A. V., Delille, B., Loscher, C. R., Naqvi, S. W. A., Omar, A. M., and Santana-Casiano, M.: Airsea interactions of natural long-lived greenhouse gases $\left(\mathrm{CO}_{2}\right.$, $\mathrm{N}_{2} \mathrm{O}, \mathrm{CH}_{4}$ ) in a changing climate, in: Ocean-Atmosphere Interactions of Gases and Particles, edited by: Liss, P. and Johnson, M., Springer-Verlag, Berlin, Germany, 113-169, 2014.

Bakker, D. C. E., Pfeil, B., Landa, C. S., Metzl, N., O’Brien, K. M., Olsen, A., Smith, K., Cosca, C., Harasawa, S., Jones, S. D., Nakaoka, S., Nojiri, Y., Schuster, U., Steinhoff, T., Sweeney, C., Takahashi, T., Tilbrook, B., Wada, C., Wanninkhof, R., Alin, S. R., Balestrini, C. F., Barbero, L., Bates, N. R., Bianchi, A. A., Bonou, F., Boutin, J., Bozec, Y., Burger, E. F., Cai, W.-J., Castle, R. D., Chen, L., Chierici, M., Currie, K., Evans, W., Featherstone, C., Feely, R. A., Fransson, A., Goyet, C., Greenwood, N., Gregor, L., Hankin, S., Hardman-Mountford, N. J., Harlay, J., Hauck, J., Hoppema, M., Humphreys, M. P., Hunt, C. W., Huss, B., Ibánhez, J. S. P., Johannessen, T., Keeling, R., Kitidis, V., Körtzinger, A., Kozyr, A., Krasakopoulou, E., Kuwata, A., Landschützer, P., Lauvset, S. K., Lefèvre, N., Lo Monaco, C., Manke, A., Mathis, J. T., Merlivat, L., Millero, F. J., Monteiro, P. M. S., Munro, D. R., Murata, A., Newberger, T., Omar, A. M., Ono, T., Paterson, K., Pearce, D., Pierrot, D., Robbins, L. L., Saito, S., Salisbury, J., Schlitzer, R., Schneider, B., Schweitzer, R., Sieger, R., Skjelvan, I., Sullivan, K. F., Sutherland, S. C., Sutton, A. J., Tadokoro, K., Telszewski, M., Tuma, M., van Heuven, S. M. A. C., Vandemark, D., Ward, B., Watson, A. J., and Xu, S.: A multidecade record of high-quality $f \mathrm{CO}_{2}$ data in version 3 of the Sur- 
face Ocean $\mathrm{CO}_{2}$ Atlas (SOCAT), Earth Syst. Sci. Data, 8, 383413, https://doi.org/10.5194/essd-8-383-2016, 2016

Bange, H. W., Bartell, U. H., Rapsomanikis, S., and Andreae, M. O.: Methane in the Baltic and North Seas and a reassessment of the marine emissions of methane, Global Biogeochem. Cy., 8, 465-480, 1994.

Bange, H. W., Rapsomanikis, S., and Andreae, M. O.: Nitrous oxide in coastal waters, Global Biogeochem. Cy., 10, 197-207, 1996.

Bange, H. W., Bell, T. G., Cornejo, M., Freing, A., Uher, G., UpstillGoddard, R. C., and Zhang, G.: MEMENTO: a proposal to develop a database of marine nitrous oxide and methane measurements, Environ. Chem., 6, 195-197, 2009.

Bange, H. W., Arévalo-Martínez, D. L., de la Paz, M., Farías, L., Kaiser, J., Kock, A., Law, C. S., Rees, A. P., Rehder, G., Tortell, P. D., Upstill-Goddard, R. C., and Wilson, S. T.: A harmonized nitrous oxide $\left(\mathrm{N}_{2} \mathrm{O}\right)$ ocean observation network for the 21st Century, Front. Mar. Sci., 6, 157, https://doi.org/10.3389/fmars.2019.00157, 2019.

Barnes, J. and Upstill-Goddard, R. C.: $\mathrm{N}_{2} \mathrm{O}$ seasonal distributions and air-sea exchange in UK estuaries: Implications for the tropospheric $\mathrm{N}_{2} \mathrm{O}$ source from European coastal waters, J. Geophys. Res.-Biogeo., 116, G01006, https://doi.org/10.1029/2009JG001156, 2011.

Battaglia, G. and Joos, F.: Marine $\mathrm{N}_{2} \mathrm{O}$ emissions from nitrification and denitrification constrained by modern observations and projected in multimillennial global warming simulations, Global Biogeochem. Cy., 32, 92-121, https://doi.org/10.1002/2017GB005671, 2018.

Berchet, A., Pison, I., Crill, P. M., Thornton, B., Bousquet, P., Thonat, T., Hocking, T., Thanwerdas, J., Paris, J.-D., and Saunois, M.: Using ship-borne observations of methane isotopic ratio in the Arctic Ocean to understand methane sources in the Arctic, Atmos. Chem. Phys., 20, 3987-3998, https://doi.org/10.5194/acp-20-3987-2020, 2020.

Biastoch, A., Treude, T., Rüpke, L. H., Riebesell, U., Roth, C., Burwicz, E. B., Park, W., Latif, M., Böning, C. W., Madec, G., and Wallmann, K.: Rising Arctic Ocean temperatures cause gas hydrate destabilization and ocean acidification, Geophys. Res. Lett., 38, L08602, https://doi.org/10.1029/2011GL047222, 2011.

Bižić, M., Klintzsch, T., Ionescu, D., Hindiyeh, M. Y., Gunthel, M., Muro-Pastor, A. M., Eckert, W., Urich, T., Keppler, F., and Grossart, H.-P.: Aquatic and terrestrial cyanobacteria produce methane, Sci. Adv., 6, eaax5343, https://doi.org/10.1126/sciadv.aax5343, 2020.

Bodelier, P. L. and Steenbergh, A. K.: Interactions between methane and the nitrogen cycle in light of climate change, Curr. Opin. Environ. Sustain., 9, 26-36, 2014.

Bonaglia, S., Brüchert, V., Callac, N., Vicenzi, A., Fru, E. C., and Nascimento, F. J. A.: Methane fluxes from coastal sediments are enhanced by macrofauna, Sci. Rep.-UK, 7, 1-10, 2017.

Boetius, A. and Wenzhöfer, F.: Seafloor oxygen consumption fuelled by methane from cold seeps, Nat. Geosci., 6, 725-734, 2013.

Borges A. V. and Abril, G.: Carbon dioxide and methane dynamics in estuaries, in: Treatise on Estuarine and Coastal Science, Vol. 5, Biogeochemistry, edited by: Wolanski, E. and McLusky, D., Academic Press, Waltham, 119-161,2011.

Borges, A. V., Champenois, W., Gypens, N., Delille, B., and Harlay, J.: Massive marine methane emissions from near-shore shallow coastal areas, Sci. Rep.-UK, 6, 27908, https://doi.org/10.1038/srep27908, 2016.

Borges A. V., Speeckaert, G., Champenois, W., Scranton, M. I., and Gypens N.: Productivity and temperature as drivers of seasonal and spatial variations of dissolved methane in the Southern Bight of the North Sea, Ecosystems, 21, 583-599, https://doi.org/10.1007/s10021-017-0171-7, 2018.

Borges, A. V., Royer, C., Lapeya Martin, J., Champenois, W., and Gypens, N.: Response to the European 2018 heatwave of marine methane emission in the Southern North Sea, Cont. Shelf Res. 190, 104004, https://doi.org/10.1016/j.csr.2019.104004, 2019.

Bourbonnais, A., Letscher, R. T., Bange, H. W., Echevin, V., Larkum, J., Mohn, J., Yoshida, N., and Altabet, M. A.: $\mathrm{N}_{2} \mathrm{O}$ production and consumption from stable isotopic and concentration data in the Peruvian coastal upwelling system, Global Biogeochem. Cy., 31, 678-698, https://doi.org/10.1002/2016GB005567, 2017.

Brase, L., Bange, H. W., Lendt, R., Sanders, T., and Dähnke, K.: High resolution measurements of nitrous oxide $\left(\mathrm{N}_{2} \mathrm{O}\right)$ in the Elbe Estuary, Front. Mar. Sci., 4, 162, https://doi.org/10.3389/fmars.2017.00162, 2017.

Breider, F., Yoshikawa, C., Makabe, A., Toyoda, S., Wakita, M., Matsui, Y., Kawagucci, S., Fujiki, T., Harada, N., and Yoshida, $\mathrm{N}$.: Response of $\mathrm{N}_{2} \mathrm{O}$ production rate to ocean acidification in the western North Pacific, Nat. Clim. Change, 9, 954-958, 2019.

Buchwald, C., Grabb, K., Hansel, C. M., and Wankel, S. D.: Constraining the role of iron in environmental nitrogen transformations: Dual stable isotope systematics of abiotic $\mathrm{NO}_{2}^{-}$reduction by $\mathrm{Fe}$ (II) and its production of $\mathrm{N}_{2} \mathrm{O}$, Geochim. Cosmochim. Ac., 186, 1-12, 2016.

Buitenhuis, E. T., Suntharalingam, P., and Le Quéré, C.: Constraints on global oceanic emissions of $\mathrm{N}_{2} \mathrm{O}$ from observations and models, Biogeosciences, 15, 2161-2175, https://doi.org/10.5194/bg15-2161-2018, 2018.

Bullister, J. L., Wisegarver, D. P., and Wilson, S. T.: The production of Methane and Nitrous Oxide Gas Standards for Scientific Committee on Ocean Research (SCOR) Working Group \#143, pp. 1-9, 2016.

Burke, K. D., Williams, J. W., Chandler, M. A., Haywood, A. M., Lunt, D. J., and Otto-Bliesner, B. L.: Pliocene and Eocene provide best analogs for near-future climates, P. Natl. Acad. Sci. USA, 115, 13288-13293, 2018.

Call, M., Maher, D. T., Santos, I. R., Ruiz-Halpern, S., Mangion, P., Sanders, C. J., Erler, D. V., Oakes, J. M., Rosentreter, J., Murray, R., and Eyre, B. D.: Spatial and temporal variability of carbon dioxide and methane fluxes over semi-diurnal and spring-neapspring timescales in a mangrove creek, Geochim. Cosmochim. Ac., 150, 211-225, 2015.

Caranto, J. D. and Lancaster, K. M.: Nitric oxide is an obligate bacterial nitrification intermediate produced by hydroxylamine oxidoreductase, P. Natl. Acad. Sci. USA, 114, 8217-8222, 2017.

Carini, P., White, A. E., Campbell, E .O., and Giovannoni, S. J.: Methane production by phosphate-starved SAR11 chemoheterotrophic marine bacteria, Nat. Commun., 5, 1-7, 2014.

Carini, P., Dupont, C. L., and Santoro, A. E.: Patterns of thaumarchaeal gene expression in culture and diverse marine environments, Environ. Microbiol., 20, 2112-2124, https://doi.org/10.1111/1462-2920.14107, 2018. 
Casciotti, K. L., Forbes, M., Vedamati, J., Peters, B., Martin, T., and Mordy, C. W.: Nitrous oxide cycling in the Eastern Tropical South Pacific as inferred from isotopic and isotopomeric data, Deep Sea Res. Pt. II, 156, 155-167, https://doi.org/10.1016/J.DSR2.2018.07.014, 2018.

Chan, E. W., Shiller, A. M., Joung D. J., Arrington, E. C., Valentine, D. L., Redmond, M. C., Breier, A., Socolofsky, A., and Kessler J. D.: Investigations of aerobic methane oxidation in two marine seep environments: Part 1 - Chemical Kinetics, J. Geophys. Res.Oceans, 12, 8852-8868, https://doi.org/10.1029/2019jc015594, 2019.

Charpentier, J., Farías, L., and Pizarro, O.: Nitrous oxide fluxes in the central and eastern South Pacific, Global Biogeochem. Cy., 24, GB3011, https://doi.org/10.1029/2008GB003388, 2010.

Ciais, P., Sabine, C., Bala, G., Bopp, L., Brovkin, V., Canadell, J., Chhabra, A., DeFries, R., Galloway, J., Heimann, M., Jones, C., Quéré, C. Le, Myneni, R. B., Piao, S., and Thornton, P.: Carbon and other biogeochemical cycles, in: Climate Change 2013: The Physical Science Basis. Contribution of Working Group 1 to the Fifth Assessment Report of the Intergovernmental Panel on Climate Change, edited by: Stocker, T., Qin, D., Plattner, G.-K., Tignor, M., Allen, S., Boschung, J., Nauels, A., Xia, Y., Bex, V., and Midgley, P., Cambridge University Press, Cambridge, UK, New York, NY, 2013.

Conthe, M., Lycus, P., Arntzen, M. Ø., da Silva, A. R., Frostegård, A., Bakken, L. R., and van Loosdrecht, M. C.: Denitrification as an $\mathrm{N}_{2} \mathrm{O}$ sink, Water Res., 151, 381-387, 2019.

Damm, E., Thoms, S., Beszczynska-Möller, A., Nöthig, E. M., and Kattner, G.: Methane excess production in oxygen-rich polar water and a model of cellular conditions for this paradox, Polar Sci., 9, 327-334, 2015.

de la Paz, M., García-Ibáñez, M. I., Steinfeldt, R., Ríos, A. F., and Pérez, F. F.: Ventilation versus biology: What is the controlling mechanism of nitrous oxide distribution in the North Atlantic?, Global Biogeochem. Cyc., 31, 745-760, https://doi.org/10.1002/2016GB005507, 2017.

Dickey, T. D.: Emerging ocean observations for interdisciplinary data assimilation systems, J. Mar. Sys., 40, 5-48, 2003.

Dickson, A. G., Sabine, C. L. and Christian, J. R.: Guide to Best Practices for Ocean $\mathrm{CO}_{2}$ Measurements, PICES Special Publication, North Pacific Marine Science Organization, Sidney, Canada, 2007.

Dickson, A.G.: Standards for ocean measurements, Oceanogr., 23, 34-47, 2010.

Dore, J. E. and Karl, D. M.: Nitrification in the euphotic zone as a source for nitrite, nitrate, and nitrous oxide at Station ALOHA, Limnol. Oceanogr., 41, 1619-1628, 1996.

Douglas, P. M. J., Stolper, D. A., Smith, D. A., Anthony, K. W., Paull, C. K., Dallimore, S., Wik, M., Crill, P. M., Winterdahl, M., Eiler, J. M., and Sessions, A. L.: Diverse origins of Arctic and Subarctic methane point source emissions identified with multiply-substituted isotopologues, Geochim. Cosmochim. Ac., 188, 163-188, 2016.

Douglas, P. M., Stolper, D. A., Eiler, J. M., Sessions, A. L., Lawson, M., Shuai, Y., Bishop, A., Podlaha, O. G., Ferreira, A. A., Neto, E. V. S., and Niemann, M.: Methane clumped isotopes: Progress and potential for a new isotopic tracer, Organic Geochem., 113, 262-282, 2017.
Erler, D. V., Duncan, T. M., Murray, R., Maher, D. T., Santos, I. R., Gatland, J. R., Mangion, P., and Eyre, B. D.: Applying cavity ring-down spectroscopy for the measurement of dissolved nitrous oxide concentrations and bulk nitrogen isotopic composition in aquatic systems: Correcting for interferences and field application, Limnol. Oceanogr.-Meth,, 13, 391-401, 2015.

Ettwig, K. F., Butler, M. K., Le Paslier, D., Pelletier, E., Mangenot, S., Kuypers, M. M., Schreiber, F., Dutilh, B. E., Zedelius, J., de Beer, D., and Gloerich, J.: Nitrite-driven anaerobic methane oxidation by oxygenic bacteria, Nature, 464, 543-548, 2010. Ettwig, K. F., Zhu, B., Speth, D., Keltjens, J. T., Jetten, M. S., and Kartal, B.: Archaea catalyze iron-dependent anaerobic oxidation of methane, P. Natl. Acad. Sci. USA, 113, 12792-12796, 2016.

Farías, L., Besoain, V., and García-Loyola, S.: Presence of nitrous oxide hotspots in the coastal upwelling area off central Chile: an analysis of temporal variability based on ten years of a biogeochemical time series, Environ. Res. Lett., 10, 044017, https://doi.org/10.1088/1748-9326/10/4/044017, 2015.

Fenwick, L., Capelle, D., Damm, E., Zimmermann, S., Williams, W. J., Vagle, S., and Tortell, P. D.: Methane and nitrous oxide distributions across the North American Arctic Ocean during summer, 2015, J. Geophys. Res.-Ocean., 122, 390-412, https://doi.org/10.1002/2016JC012493, 2017.

Ferrón, S., Ortega, T., Gómez-Parra, A., and Forja, J. M.: Seasonal study of dissolved $\mathrm{CH}_{4}, \mathrm{CO}_{2}$ and $\mathrm{N}_{2} \mathrm{O}$ in a shallow tidal system of the bay of Cádiz (SW Spain), J. Mar. Sys., 66, 244-257, 2007.

Foster, S. Q. and Fulweiler, R. W.: Estuarine sediments exhibit dynamic and variable biogeochemical responses to hypoxia, J. Geophys. Res.-Biogeosci., 124, 737-758, 2019.

Foucher, J. P., Westbrook, G. K., Boetius, A. N., Ceramicola, S. I., Dupré, S., Mascle, J., Mienert, J., Pfannkuche, O., Pierre, C., and Praeg D.: Structure and drivers of cold seep ecosystems, Oceanography, 22, 92-109, 2009.

Frame, C. H. and Casciotti, K. L.: Biogeochemical controls and isotopic signatures of nitrous oxide production by a marine ammonia-oxidizing bacterium, Biogeosciences, 7, 2695-2709, https://doi.org/10.5194/bg-7-2695-2010, 2010.

Frame, C. H., Deal, E., Nevison, C. D., and Casciotti, K. L.: $\mathrm{N}_{2} \mathrm{O}$ production in the eastern South Atlantic: Analysis of $\mathrm{N}_{2} \mathrm{O}$ stable isotopic and concentration data, Global Biogeochem. Cyc., 28, 1262-1278, 2014.

Frey, C., Bange, H. W., Achterberg, E. P., Jayakumar, A., Löscher, C. R., Arévalo-Martínez, D. L., León-Palmero, E., Sun, M., Sun, X., Xie, R. C., Oleynik, S., and Ward, B. B.: Regulation of nitrous oxide production in low-oxygen waters off the coast of Peru, Biogeosciences, 17, 2263-2287, https://doi.org/10.5194/bg-172263-2020, 2020.

Fuchsman, C. A., Devol, A. H., Saunders, J. K., McKay, C., and Rocap, G.: Niche partitioning of the N cycling microbial community of an offshore oxygen deficient zone, Front. Microbiol., 8, 2384, https://doi.org/10.3389/fmicb.2017.02384, 2017.

Ganesan, A. L., Schwietzke, S., Poulter, B., Arnold, T., Lan, X., Rigby, M., Vogel, F. R., van der Werf, G. R., Janssens-Maenhout, 5 G., Boesch, H., Pandey, S., Manning, A. J., Jackson, R. B., Nisbet, E. G., and Manning, M. R.: Advancing Scientific Understanding of the Global Methane Budget in Support of the Paris Agreement, Global Biogeochem. Cy., 33, 1475-1512, https://doi.org/10.1029/2018GB006065, 2019. 
Ganesan, A. L., Manizza, M., Morgan, E. J., Harth, C. M., Kozlova, E., Lueker, T., Manning, A. J., Lunt, M. F., Mühle, J., Lavric, J. V., and Heimann, M.: Marine nitrous oxide emissions from three Eastern Boundary Upwelling Systems inferred from atmospheric observations, Geophys. Res. Lett., 47, e2020GL087822, https://doi.org/10.1029/2020GL087822, 2020.

Ganesh, S., Parris, D. J., DeLong, E. F., and Stewart, F. J.: Metagenomic analysis of size-fractionated picoplankton in a marine oxygen minimum zone, ISME J., 8, 187-211, 2014.

Garcia-Tigreros, F. and Kessler, J. D.: Limited acute influence of aerobic methane oxidation on ocean carbon dioxide and $\mathrm{pH}$ in Hudson Canyon, northern US Atlantic margin, J. Geophys. Res.Biogeosci., 123, 2135-2144, 2018.

Gelesh, L., Marshall, K., Boicourt, W., and Lapham, L.: Methane concentrations increase in bottom waters during summertime anoxia in the highly eutrophic estuary, Chesapeake Bay, USA, Limnol. Oceanogr., 61, S253-S266, 2016.

Goreau, T. J., Kaplan, W. A., Wofsy, S. C., McElroy, M. B., Valois, F. W., and Watson, S.W.: Production of $\mathrm{NO}_{2}^{-}$and $\mathrm{N}_{2} \mathrm{O}$ by nitrifying bacteria at reduced concentrations of oxygen, Appl. Environ. Microbiol., 40, 526-532, 1980.

Gülzow, W., Rehder, G., Schneider, B., Schneider, J., Deimling, V., and Sadkowiak, B.: A new method for continuous measurement of methane and carbon dioxide in surface waters using off-axis integrated cavity output spectroscopy (ICOS): An example from the Baltic Sea, Limnol. Oceanogr. Method., 9, 176-184, 2011.

Gülzow, W., Rehder, G., Schneider von Deimling, J., Seifert, S., and Tóth, Z.: One year of continuous measurements constraining methane emissions from the Baltic Sea to the atmosphere using a ship of opportunity, Biogeosciences, 10, 81-99, https://doi.org/10.5194/bg-10-81-2013, 2013.

Gutiérrez-Loza, L., Wallin, M. B., Sahlée, E., Nilsson, E., Bange, H. W., Kock, A., and Rutgersson, A.: Measurement of air-sea methane fluxes in the Baltic Sea using the eddy covariance method, Front. Earth Sci., 7, 93, https://doi.org/10.3389/feart.2019.00093, 2019.

Hallin, S., Philippot, L., Löffler, F. E., Sanford, R. A., and Jones, C. M.: Genomics and ecology of novel $\mathrm{N}_{2} \mathrm{O}$-reducing microorganisms, Trends Microbiol., 26, 43-55, 2018.

Haroon, M. F., Hu, S., Shi, Y., Imelfort, M., Keller, J., Hugenholtz, P., Yuan, Z., and Tyson, G. W.: Anaerobic oxidation of methane coupled to nitrate reduction in a novel archaeal lineage, Nature, 500, 567-570, https://doi.org/10.1038/nature12375, 2013.

Harris, S. J., Liisberg, J., Xia, L., Wei, J., Zeyer, K., Yu, L., Barthel, M., Wolf, B., Kelly, B. F. J., Cendón, D. I., Blunier, T., Six, J., and Mohn, J.: $\mathrm{N}_{2} \mathrm{O}$ isotopocule measurements using laser spectroscopy: analyzer characterization and intercomparison, Atmos. Meas. Tech., 13, 2797-2831, https://doi.org/10.5194/amt13-2797-2020, 2020.

Hink, L., Lycus, P., Gubry-Rangin, C., Frostegård, Å., Nicol, G. W., Prosser, J. I., and Bakken, L. R.: Kinetics of $\mathrm{NH}_{3}$-oxidation, NOturnover, $\mathrm{N}_{2} \mathrm{O}$-production and electron flow during oxygen depletion in model bacterial and archaeal ammonia oxidizers, Environ. Microbiol., 19, 4882-4896, 2017.

Ho, D. T., Schlosser, P., and Orton, P. M.: On factors controlling air-water gas exchange in a large tidal river, Estuar. Coasts, 34, 1103-1116, 2011.

Hofman, T.: Oceanic nitrous oxide and methane, $6 \mathrm{~min}$ video, Publicly available via the German National
Library of Science and Technology (TIB) with the DOI https://doi.org/10.5446/50062, available at: https: $/ /$ www.youtube.com/watch? $=0$ DyMyIVs4Qs\&t=266s $\quad$ (last access: 20 November 2020), 2019.

Hopkins, F. E., Suntharalingam, P., Gehlen, M., Andrews, O., Archer, S. D., Bopp, L., Buitenhuis, E., Dadou, I., Duce, R., Goris, N., and Jickells, T.: The impacts of ocean acidification on marine trace gases and the implications for atmospheric chemistry and climate, Proc. R. Soc. A, 476, 20190769, https://doi.org/10.1098/rspa.2019.0769, 2020.

Huang, J., Luo, M., Liu, Y., Zhang, Y., and Tan, J.: Effects of tidal scenarios on the methane emission dynamics in the subtropical tidal marshes of the Min River Estuary in Southeast China, Internat. J. Environ. Res. Publ. Health, 16, 2790, https://doi.org/10.3390/ijerph16152790, 2019.

IPCC: In Climate Change: The Physical Science Basis. Contribution of Working Group I to the Fifth Assessment Report of the Intergovernmental Panel on Climate Change 2013, edited by: Stocker, T. F., Qin, D., Plattner, G.-K., Tignor, M., Allen, S. K., Boschung, J., Nauels, A., Xia, Y., Bex ,V., and Midgley, P. M., Cambridge University Press, Cambridge, United Kingdom and New York, NY, USA, 2013.

IPCC: Summary for Policymakers, in: IPCC Special Report on the Ocean and Cryosphere in a Changing Climate, edited by: Pörtner,H.-O., Roberts, D.C., Masson-Delmotte, V., Zhai, P., Tignor, M., Poloczanska, E., Mintenbeck, K., Nicolai, M., Okem, A., Petzold, J., Rama, B., and Weyer, N., 2019.

James, R. H., Bousquet, P., Bussmann, I., Haeckel, M., Kipfer, R., Leifer, I., Niemann, H., Ostrovsky, I., Piskozub, J., Rehder, G., and Treude, T.: Effects of climate change on methane emissions from seafloor sediments in the Arctic Ocean: A review, Limnol. Oceanogr., 61, S283-S299, 2016.

Jeffrey, L. C., Maher, D. T., Santos, I. R., Call, M., Reading, M. J., Holloway, C., and Tait, D. R.: The spatial and temporal drivers of $\mathrm{pCO}_{2}, \mathrm{pCH}_{4}$ and gas transfer velocity within a subtropical estuary, Estuar. Coast Shelf Sci., 208, 83-95, 2018.

Ji, Q. and Ward, B. B.: Nitrous oxide production in surface waters of the mid-latitude North Atlantic Ocean, J. Geophys. Res.-Ocean., 122, 2612-2621, https://doi.org/10.1002/2016JC012467, 2017.

Ji, Q., Babbin, A. R., Jayakumar, A., Oleynik, S., and Ward, B. B.: Nitrous oxide production by nitrification and denitrification in the Eastern Tropical South Pacific oxygen minimum zone, Geophys. Res. Lett., 42, 10-755, 2015.

Ji, Q., Buitenhuis, E., Suntharalingam, P., Sarmiento, J. L., and Ward, B. B.: Global nitrous oxide production determined by oxygen sensitivity of nitrification and denitrification, Global Biogeochem. Cy., 32, 1790-1802, https://doi.org/10.1029/2018GB005887, 2018.

Jordan, S. F., Treude, T., Leifer, I., Janßen, R., Werner, J., SchulzVogt, H., and Schmale, O.: Bubble-mediated transport of benthic microorganisms into the water column: Identification of methanotrophs and implication of seepage intensity on transport efficiency, Sci. Rep.-UK, 10, 1-15, 2020.

Karl, D. M., Beversdorf, L., Björkman, K. M., Church, M. J., Martinez, A., and Delong, E. F.: Aerobic production of methane in the sea, Nat. Geosci., 1, 473-478, 2008.

Kessler, J. D. and Reeburgh, W. S.: Preparation of natural methane samples for stable isotope and radiocar- 
bon analysis, Limnol. Oceanogr.-Meth., 3, 408-418, https://doi.org/10.4319/lom.2005.3.408, 2005.

Kessler, J. D., Reeburgh, W. S., Valentine, D. L., Kinnaman, F. S., Peltzer, E. T., Brewer, P. G., Southon, J., and Tyler, S. C.: A survey of methane isotope abundance $\left({ }^{14} \mathrm{C},{ }^{13} \mathrm{C},{ }^{2} \mathrm{H}\right)$ from five nearshore marine basins that reveals unusual radiocarbon levels in subsurface waters, J. Geophys. Res.-Oceans, 113, C12021, https://doi.org/10.1029/2008jc004822, 2008.

Klintzsch, T., Langer, G., Nehrke, G., Wieland, A., Lenhart, K., and Keppler, F.: Methane production by three widespread marine phytoplankton species: release rates, precursor compounds, and potential relevance for the environment, Biogeosciences, 16, 4129-4144, https://doi.org/10.5194/bg-16-4129-2019, 2019.

Kock, A. and Bange, H. W.: Counting the ocean's greenhouse gas emissions, Eos, 96, 10-13, https://doi.org/10.1029/2015EO023665, 2015.

Kodovska, F. G. T., Sparrow, K. J., Yvon-Lewis, S. A., Paytan, A., Dimova, N. T., Lecher, A., and Kessler, J. D.: Dissolved methane and carbon dioxide fluxes in Subarctic and Arctic regions: Assessing measurement techniques and spatial gradients, Earth Planet. Sci. Lett., 436, 43-55, 2016.

Kosmach, D. A., Sergienko, V. I., Dudarev, O. V., Kurilenko, A. V., Gustafsson, O., Semiletov, I. P., and Shakhova, N. E.: Methane in the surface waters of Northern Eurasian marginal seas, Doklady Chemistry, 465, 281-285, 2015.

Kremer, J. N., Reischauer, A., and D’Avanzo, C.: Estuary-specific variation in the air-water gas exchange coefficient for oxygen, Estuaries, 26, 829-836, 2003.

Labidi, J., Young, E. D., Giunta, T., Kohl, I. E., Seewald, J., Tang, H., Lilley, M. D., and Fruh-Green, G. L.: Methane thermometry in deep-sea hydrothermal systems: evidence for re-ordering of doubly-substituted isotopologues during fluid cooling, Geochim. Cosmochim. Ac., 88, 248-261, 2020.

Lan, X., Tans, P., Sweeney, C., Andrews, A., Dlugokencky, E., Schwietzke, S., Kofler, J., McKain, K., Thoning, K., Crotwell, M., and Montzka, S.: Long-term measurements show little evidence for large increases in total U.S. methane emissions over the past decade, Geophys. Res. Lett., 46, 4991-4999, https://doi.org/10.1029/2018GL081731, 2019.

Lancaster, K. M., Caranto, J. D., Majer, S. H., and Smith, M. A.: Alternative bioenergy: Updates to and challenges in nitrification metalloenzymology, Joule, 2, 421-441, https://doi.org/10.1016/j.joule.2018.01.018, 2018.

Landolfi, A., Somes, C. J., Koeve, W., Zamora, L. M., and Oschlies, A.: Oceanic nitrogen cycling and $\mathrm{N}_{2} \mathrm{O}$ flux perturbations in the Anthropocene, Global Biogeochem. Cy., 31, 1236-1255, https://doi.org/10.1002/2017GB005633, 2017. Lapham, L., Wilson, R., Riedel, M., Paull, C. K., and Holmes, M. E.: Temporal variability of in situ methane concentrations in gas hydratebearing sediments near Bullseye Vent, Northern Cascadia Margin, Geochem. Geophy. Geosy., 14, 2445-2459, 2013.

Lapham, L., Marshall, K., Magen, C., Lyubchich, V., Cooper, L. W., and Grebmeier, J. M.: Dissolved methane concentrations in the water column and surface sediments of Hanna Shoal and Barrow Canyon, Northern Chukchi Sea, Deep. Sea. Res., 144, 92-103, 2017.

Leonte, M., Kessler, J. D., Kellermann, M. Y., Arrington, E. C., Valentine, D. L., and Sylva, S. P.: Rapid rates of aerobic methane oxidation at the feather edge of gas hydrate stability in the waters of Hudson Canyon, US Atlantic Margin, Geochim. Cosmochim. Ac., 204, 375-387, https://doi.org/10.1016/j.gca.2017.01.009, 2017.

Leonte, M., Wang, B., Socolofsky, S. A., Mau, S., Breier, J. A., and Kessler, J. D.: Using carbon isotope fractionation to constrain the extent of methane dissolution into the water column surrounding a natural hydrocarbon gas seep in the Northern Gulf of Mexico, Geochem. Geophy. Geosy., 19, 4459-4475, https://doi.org/10.1029/2018gc007705, 2018.

Leonte, M., Ruppel, C. D., Ruiz-Angulo, A., and Kessler, J. D.: Surface methane concentrations along the Mid-Atlantic Bight driven by aerobic subsurface production rather than seafloor gas seeps, J. Geophys. Res.-Oceans, 125, e2019JC015989, https://doi.org/10.1029/2019JC015989, 2020.

Li, Y., Fichot, C. G., Geng, L., Scarratt, M. G., and Xie, H.: The contribution of methane photoproduction to the oceanic methane paradox, Geophys. Res. Lett., 47, e2020GL088362, https://doi.org/10.1029/2020GL088362, 2020.

Lohrberg, A., Schmale, O., Ostrovsky, I., Niemann, H., Held, P., and Schneider von Deimling, J.: Discovery and quantification of a widespread methane ebullition event in a coastal inlet (Baltic Sea) using a novel sonar strategy, Sci. Rep.-UK, 10, 4393, https://doi.org/10.1038/s41598-020-60283-0, 2020.

Lorenson, T. D., Greinert, J., and Coffin, R. B.: Dissolved methane in the Beaufort Sea and the Arctic Ocean, 1992-2009; sources and atmospheric flux, Limnol. Oceanogr., 61, S300-S323, 2016.

Löscher, C. R., Kock, A., Könneke, M., LaRoche, J., Bange, H. W., and Schmitz, R. A.: Production of oceanic nitrous oxide by ammonia-oxidizing archaea, Biogeosciences, 9, 2419-2429, https://doi.org/10.5194/bg-9-2419-2012, 2012.

Lycus, P., Bøthun, K. L., Bergaust, L., Shapleigh, J. P., Bakken, L. R., and Frostegård, Å.: Phenotypic and genotypic richness of denitrifiers revealed by a novel isolation strategy, ISME J., 11, 2219-2232, 2017.

Ma, X., Lennartz, S. T., and Bange, H. W.: A multi-year observation of nitrous oxide at the Boknis Eck Time Series Station in the Eckernförde Bay (southwestern Baltic Sea), Biogeosciences, 16, 4097-4111, https://doi.org/10.5194/bg-16-4097-2019, 2019.

Maher, D. T., Cowley, K., Santos, I. R., Macklin, P., and Eyre, B. D.: Methane and carbon dioxide dynamics in a subtropical estuary over a diel cycle: Insights from automated in situ radioactive and stable isotope measurements, Mar. Chem., 168, 69-79, 2015.

Maher, D. T., Sippo, J. Z., Tait, D. R., Holloway, C., and Santos, I. R., Pristine mangrove creek waters are a sink of nitrous oxide, Sci. Rep.-UK, 6, 25701, https://doi.org/10.1038/srep25701, 2016.

Maher, D. T., Drexl, M., Tait, D. R., Johnston, S. G., and Jeffrey, L. C.: iAMES: An inexpensive automated methane ebullition sensor, Environ. Sci. Technol., 53, 6420-6426, 2019.

Manning, C. C., Preston, V. L., Jones, S. F., Michel, A. P. M., Nicholson, D. P., Duke, P. J., Ahmed, M. M. M., Manganini, K., Else, B. G. T., and Tortell, P. D.: River inflow dominates methane emissions in an Arctic coastal system, Geophys. Res. Lett., 47 e2020GL087669, https://doi.org/10.1029/2020GL087669, 2020

Marchant, H. K., Ahmerkamp, S., Lavik, G., Tegetmeyer, H. E., Graf, J., Klatt, J. M., Holtappels, M., Walpersdorf, E., and Kuypers, M. M.: Denitrifying community in coastal sediments performs aerobic and anaerobic respiration simultaneously, ISME J., 11, 1799-1812, 2017. 
Marchant, H. K., Tegetmeyer, H. E., Ahmerkamp, S., Holtappels, M., Lavik G., Graf, J., Schreiber, F., Mussmann, M., Strous M., and Kuypers M. M. M.: Metabolic specialization of denitrifiers in permeable sediments controls $\mathrm{N}_{2} \mathrm{O}$ emissions, Environ. Microbiol., 20, 4486-4502, https://doi.org/10.1111/1462-2920.14385, 2018.

Mau, S., Heintz, M. B., and Valentine, D. L.: Quantification of $\mathrm{CH}_{4}$ loss and transport in dissolved plumes of the Santa Barbara Channel, California, Cont. Shelf Res., 32, 110-120, https://doi.org/10.1016/j.csr.2011.10.016, 2012.

McDermitt, D., Burba, G., Xu, L., Anderson, T., Komissarov, A., Riensche, B., Schedlbauer, J., Starr, G., Zona, D., Oechel, W., Oberbauer, S., and Hastings, S.: A new low-power, open-path instrument for measuring methane flux by eddy covariance, Appl. Phys. B, 102, 391-405, 2011

Molstad, L., Dörsch, P., and Bakken, L. R.: Robotized incubation system for monitoring gases $\left(\mathrm{O}_{2}, \mathrm{NO}, \mathrm{N}_{2} \mathrm{O} \mathrm{N} \mathrm{N}_{2}\right)$ in denitrifying cultures, J. Microbiol. Methods, 71, 202-211, 2007.

Montzka, S. A., Dlugokencky, E. J., and Butler, J. H.: Non$\mathrm{CO}_{2}$ greenhouse gases and climate change, Nature, 476, 4350, 2011. Müller, D., Bange, H. W., Warneke, T., Rixen, T., Müller, M., Mujahid, A., and Notholt, J.: Nitrous oxide and methane in two tropical estuaries in a peat-dominated region of northwestern Borneo, Biogeosciences, 13, 2415-2428, https://doi.org/10.5194/bg-13-2415-2016, 2016.

Murray, R. H., Erler, D. V., and Eyre, B. D.: Nitrous oxide fluxes in estuarine environments: response to global change, Glob. Change Biol., 21, 3219-3245, 2015.

Murray, R., Erler, D. V., Rosentreter, J., Wells, N. S., and Eyre, B. D.: Seasonal and spatial controls on $\mathrm{N}_{2} \mathrm{O}$ concentrations and emissions in low-nitrogen estuaries: Evidence from three tropical systems, Mar. Chem., 103779, https://doi.org/10.1016/j.marchem.2020.103779, 2020.

Nemitz, E., Mammarella, I., Ibrom, A., Aurela, M., Burba, G. G., Dengel, S., Gielen, B., Grelle, A., Heinesch, B., Herbst, M., Hörtnagl, L., Klemedtsson, L., Lindroth, A., Lohila, A., McDermitt, D. K., Meier, P., Merbold, L., Nelson, D., Nicolini, G., Nilsson, M. B., Peltola. O., Rinne, J., and Zahniser, M.: Standardisation of eddy-covariance flux measurements of methane and nitrous oxide, Int. Agrophys., 32, 517-549, 2018.

Nicholson, D. P., Michel, A. P., Wankel, S. D., Manganini, K., Sugrue, R. A., Sandwith, Z. O., and Monk, S. A.: Rapid mapping of dissolved methane and carbon dioxide in coastal ecosystems using the ChemYak autonomous surface vehicle, Environ. Sci. Tech., 52, 13314-13324, 2018.

Nightingale, P. D., Malin, G., Law, C. S., Watson, A. J., Liss, P. S., Liddicoat, M. I., Boutin, J., and Upstill-Goddard, R. C.: In situ evaluation of air-sea gas exchange parameterizations using novel conservative and volatile tracers, Global Biogeochem. Cy., 14, 373-387, 2000.

NOAA Earth System Research Laboratory: Global Monitoring Division: Monthly averaged flask measurements of $\mathrm{CH}_{4}$ and $\mathrm{N}_{2} \mathrm{O}$ atmospheric concentrations. available at: https://www.esrl.noaa. gov/gmd/dv/data/, last access: 1 November 2020.

Novick, K. A., Biederman, J. A., Desai, A. R., Litvak, M. E., Moore, D. J., Scott, R. L., and Torn, M. S.: The AmeriFlux network: A coalition of the willing, Agr. Forest Meteorol., 249, 444-456, 2018.
Ostrom, N. E., Gandhi, H., Trubl, G., and Murray, A. E.: Chemodenitrification in the cryoecosystem of Lake Vida, Victoria Valley, Antarctica, Geobiol., 14, 575-587, 2016.

Pack, M. A., Heintz, M. B., Reeburgh, W. S., Trumbore, S. E., Valentine, D. L., Xu, X., and Druffel, E. R.: A method for measuring methane oxidation rates using low levels of ${ }^{14} \mathrm{C}$-labeled methane and accelerator mass spectrometry, Limnol. Oceanogr.Method., 9, 245-260, https://doi.org/10.4319/lom.2011.9.245, 2011.

Pankratova, N., Belikov, I., Skorokhod, A., Belousov, V., Artamonov, A., Repina, I., and Shishov, E.: Measurements and data processing of atmospheric $\mathrm{CO}_{2}, \mathrm{CH}_{4}, \mathrm{H}_{2} \mathrm{O}$ and $\delta^{13} \mathrm{C}_{-} \mathrm{CH}_{4}$ mixing ratio during the ship campaign in the East Arctic and the Far East seas in autumn 2016, Earth Environ. Sci., 231, 012041, https://doi.org/10.1088/1755-1315/231/1/012041, 2019.

Pfeiffer-Herbert, A. S., Prahl, F. G., Peterson, T. D., and Wolhowe, M.: Methane dynamics associated with tidal processes in the Lower Columbia River, Estuar. Coast., 42, 1249-1264, 2019.

Podgrajsek, E., Sahlee, E., Bastviken, D., Natchimuthu, S., Kljun, N., Chmiel, H. E., Klemedtsson, L., and Rutgersson, A.: Methane fluxes from a small boreal lake measured with the eddy covariance method, Limnol. Oceanogr., 61, S41-S50, 2016.

Pohlman, J. W., Kaneko, M., Heuer, V. B., Coffin, R. B., and Whiticar, M.: Methane sources and production in the northern Cascadia margin gas hydrate system, Earth Planetary Sci. Lett., 287, 504-512, 2009.

Pohlman, J. W., Bauer, J. E., Waite, W. F., Osburn, C. L., and Chapman, N. R.: Methane hydrate-bearing seeps as a source of aged dissolved organic carbon to the oceans, Nat. Geosci., 4, 37-41, 2011. Pohlman, J. W., Greinert, J., Ruppel, C., Silyakova, A., Vielstädte, L., Casso, M., Mienert, J., and Bünz, S.: Enhanced $\mathrm{CO}_{2}$ uptake at a shallow Arctic Ocean seep field overwhelms the positive warming potential of emitted methane, P. Natl. Acad. Sci. USA, 114, 5355-5360, 2017.

Prosser, J. I., Hink, L., Gubry-Rangin, C., and Nicol, G. W.: Nitrous oxide production by ammonia oxidizers: Physiological diversity, niche differentiation and potential mitigation strategies, Glob. Change Biol., 26, 103-118, 2020.

Qin, W., Meinhardt, K. A., Moffett, J. W., Devol, A. H., Armbrust, E.V., Ingalls, A. E., and Stahl, D. A.: Influence of oxygen availability on the activities of ammonia-oxidizing archaea, Environ. Microbiol. Reports, 9, 250-256, 2017.

Ray, N. E., Maguire, T. J., Al-Haj, A. N., Henning, M. C., and Fulweiler, R. W.: Low greenhouse gas emissions from oyster aquaculture, Environ. Sci. Technol., 53, 9118-9127, 2019.

Raymond, P. A. and Cole, J. J.: Gas exchange in rivers and estuaries: Choosing a gas transfer velocity, Estuaries, 24, 312-317, 2001.

Reading, M. J., Tait, D. R., Maher, D. T., Jeffrey, L. C., Looman, A., Holloway, C., Shishaye, H. A., Barron, S., and Santos, I. R.: Land use drives nitrous oxide dynamics in estuaries on regional and global scales, Limnol. Oceanogr., 65, 1903-1920, https://doi.org/10.1002/lno.11426, 2020.

Reeburgh, W. S.: Oceanic methane biogeochemistry, Chem. Rev., 107, 486-513, 2007.

Repeta, D. J., Ferrón, S., Sosa, O. A., Johnson, C. G., Repeta, L. D., Acker, M., DeLong, E. F., and Karl, D. M.: Marine methane paradox explained by bacterial degradation of dissolved organic matter, Nat. Geosci., 9, 884-887, 2016. 
Romanovskii, N. N., Hubberten, H. W., Gavrilov, A. V., Eliseeva, A. A., and Tipenko, G. S.: Offshore permafrost and gas hydrate stability zone on the shelf of East Siberian Seas, Geo.-Mar. Lett., 25, 167-182, 2005.

Rosentreter, J. A., Maher, D. T., Ho, D. T., Call, M., Barr, J. G., and Eyre, B. D.: Spatial and temporal variability of $\mathrm{CO}_{2}$ and $\mathrm{CH}_{4}$ gas transfer velocities and quantification of the $\mathrm{CH}_{4}$ microbubble flux in mangrove dominated estuaries, Limnol. Oceanogr., 62, 561-578, 2017.

Rosentreter, J. A., Maher, D. T., Erler, D. V., Murray, R. H., and Eyre, B. D.: Methane emissions partially offset "blue carbon" burial in mangroves, Science advances 4, eaao4985, https://doi.org/10.1126/sciadv.aao4985, 2018.

Ruppel, C. D. and Kessler, J. D.: The interaction of climate change and methane hydrates, Rev. Geophys., 55, 126-168, https://doi.org/10.1002/2016RG000534, 2017.

Santoro, A. E., Casciotti, K. L., and Francis, C. A.: Activity, abundance and diversity of nitrifying archaea and bacteria in the central California Current, Environ. Microbiol., 12, 1989-2006, 2010.

Santoro, A. E., Buchwald, C., McIlvin, M. R., and Casciotti, K. L.: Isotopic signature of $\mathrm{N}_{2} \mathrm{O}$ produced by marine ammoniaoxidizing archaea, Science, 333, 1282-1285, 2011.

Sapart, C. J., Shakhova, N., Semiletov, I., Jansen, J., Szidat, S., Kosmach, D., Dudarev, O., van der Veen, C., Egger, M., Sergienko, V., Salyuk, A., Tumskoy, V., Tison, J.-L., and Röckmann, T.: The origin of methane in the East Siberian Arctic Shelf unraveled with triple isotope analysis, Biogeosciences, 14, 2283-2292, https://doi.org/10.5194/bg-14-2283-2017, 2017.

Saunois, M., Bousquet, P., Poulter, B., Peregon, A., Ciais, P., Canadell, J. G., Dlugokencky, E. J., Etiope, G., Bastviken, D., Houweling, S., Janssens-Maenhout, G., Tubiello, F. N., Castaldi, S., Jackson, R. B., Alexe, M., Arora, V. K., Beerling, D. J., Bergamaschi, P., Blake, D. R., Brailsford, G., Brovkin, V., Bruhwiler, L., Crevoisier, C., Crill, P., Covey, K., Curry, C., Frankenberg, C., Gedney, N., Höglund-Isaksson, L., Ishizawa, M., Ito, A., Joos, F., Kim, H.-S., Kleinen, T., Krummel, P., Lamarque, J.-F., Langenfelds, R., Locatelli, R., Machida, T., Maksyutov, S., McDonald, K. C., Marshall, J., Melton, J. R., Morino, I., Naik, V., O’Doherty, S., Parmentier, F.-J. W., Patra, P. K., Peng, C., Peng, S., Peters, G. P., Pison, I., Prigent, C., Prinn, R., Ramonet, M., Riley, W. J., Saito, M., Santini, M., Schroeder, R., Simpson, I. J., Spahni, R., Steele, P., Takizawa, A., Thornton, B. F., Tian, H., Tohjima, Y., Viovy, N., Voulgarakis, A., van Weele, M., van der Werf, G. R., Weiss, R., Wiedinmyer, C., Wilton, D. J., Wiltshire, A., Worthy, D., Wunch, D., Xu, X., Yoshida, Y., Zhang, B., Zhang, Z., and Zhu, Q.: The global methane budget 2000-2012, Earth Syst. Sci. Data, 8, 697-751, https://doi.org/10.5194/essd-8-697-2016, 2016.

Saunois, M., Stavert, A. R., Poulter, B., Bousquet, P., Canadell, J. G., Jackson, R. B., Raymond, P. A., Dlugokencky, E. J., Houweling, S., Patra, P. K., Ciais, P., Arora, V. K., Bastviken, D., Bergamaschi, P., Blake, D. R., Brailsford, G., Bruhwiler, L., Carlson, K. M., Carrol, M., Castaldi, S., Chandra, N., Crevoisier, C., Crill, P. M., Covey, K., Curry, C. L., Etiope, G., Frankenberg, C., Gedney, N., Hegglin, M. I., Höglund-Isaksson, L., Hugelius, G., Ishizawa, M., Ito, A., Janssens-Maenhout, G., Jensen, K. M., Joos, F., Kleinen, T., Krummel, P. B., Langenfelds, R. L., Laruelle, G. G., Liu, L., Machida, T., Maksyutov, S., McDon- ald, K. C., McNorton, J., Miller, P. A., Melton, J. R., Morino, I., Müller, J., Murguia-Flores, F., Naik, V., Niwa, Y., Noce, S., O’Doherty, S., Parker, R. J., Peng, C., Peng, S., Peters, G. P., Prigent, C., Prinn, R., Ramonet, M., Regnier, P., Riley, W. J., Rosentreter, J. A., Segers, A., Simpson, I. J., Shi, H., Smith, S. J., Steele, L. P., Thornton, B. F., Tian, H., Tohjima, Y., Tubiello, F. N., Tsuruta, A., Viovy, N., Voulgarakis, A., Weber, T. S., van Weele, M., van der Werf, G. R., Weiss, R. F., Worthy, D., Wunch, D., Yin, Y., Yoshida, Y., Zhang, W., Zhang, Z., Zhao, Y., Zheng, B., Zhu, Q., Zhu, Q., and Zhuang, Q.: The Global Methane Budget 2000-2017, Earth Syst. Sci. Data, 12, 15611623, https://doi.org/10.5194/essd-12-1561-2020, 2020.

Schmale, O., Wage, J., Mohrholz, V., Wasmund, N., Grawe, U., Rehder, G., Labrenz, M., and Loick-Wilde, N.: The contribution of zooplankton to methane supersaturation in the oxygenated upper waters of the central Baltic Sea, Limnol. Oceanogr., 63, 412-430, 2018.

Schmidt, H. L., Werner, R. A., Yoshida, N., and Well, R.: Is the isotopic composition of nitrous oxide an indicator for its origin from nitrification or denitrification? A theoretical approach from referred data and microbiological and enzyme kinetic aspects, Rapid Comm. Mass Spec., 18, 2036-2040, 2004.

Seitzinger, S. P. and Kroeze, C.: Global distribution of nitrous oxide production and $\mathrm{N}$ inputs in freshwater and coastal marine ecosystems, Global Biogeochem. Cy., 12, 93-113, 1998.

Shakhova, N., Semiletov, I., Leifer, I., Salyuk, A., Rekant, P., and Kosmach, D.: Geochemical and geophysical evidence of methane release over the East Siberian Arctic Shelf, J. Geophys. Res-Oceans, 115, C08007, https://doi.org/10.1029/2009JC005602, 2010.

Sosa, O. A., Burrell, T. J., Wilson, S. T., Foreman, R. K., Karl, D. M., and Repeta, D. J.: Phosphonate cycling supports methane and ethylene production and supersaturation in the phosphatedepleted western North Atlantic Ocean, Limnol. Oceanogr., 65, 2443-2459, https://doi.org/10.1002/lno.11463, 2020.

Sparrow, K. J. and Kessler, J. D.: Efficient collection and preparation of methane from low concentration waters for natural abundance radiocarbon analysis, Limnol. Oceanogr.-Method., 15, 601-617, https://doi.org/10.1002/lom3.10184, 2017.

Sparrow, K. J., Kessler, J. D., Southon, J. R., Garcia-Tigreros, F., Schreiner, K. M., Ruppel, C. D., Miller, J. B., Lehman, S. J., and $\mathrm{Xu}, \mathrm{X}$.: Limited contribution of ancient methane to surface waters of the U.S. Beaufort Sea shelf, Sci. Adv., 4, eaao4842, https://doi.org/10.1126/sciadv.aao4842, 2018.

Stahl, D. A. and de la Torre, J. R.: Physiology and diversity of ammonia-oxidizing archaea, Annu. Rev. Microbiol., 66, 83-101, 2012.

Stein, L. Y. and Yung, Y. L.: Production, isotopic composition, and atmospheric fate of biologically produced nitrous oxide, Annu. Rev. Earth Planet. Sci., 31, 329-356, 2003.

Steinle, L., Graves, C. A., Treude, T., Ferré, B., Biastoch, A., Bussmann, I., Berndt, C., Krastel, S., James, R. H., Behrens, E., and Böning, C. W.: Water column methanotrophy controlled by a rapid oceanographic switch, Nat. Geosci., 8, 378-382, 2015.

Stewart, F. J., Dalsgaard, T., Young, C. R., Thamdrup, B., Revsbech, N. P., Ulloa, O., Canfield, D. E., and DeLong, E. F.: Experimental incubations elicit profound changes in community transcription in OMZ bacterioplankton, Plos One, 7, e37118, https://doi.org/10.1371/journal.pone.0037118, 2012. 
Stieglmeier, M., Mooshammer, M., Kitzler, B., Wanek, W., Zechmeister-Boltenstern, S., Richter, A., and Schleper, C.: Aerobic nitrous oxide production through $\mathrm{N}$-nitrosating hybrid formation in ammonia-oxidizing archaea, ISME J., 8, 1135-1146, 2014.

Stolper, D. A., Sessions, A. L., Ferreira, A. A., Neto, E. S., Schimmelmann, A., Shusta, S. S., Valentine, D. L., and Eiler, J. M.: Combined ${ }^{13} \mathrm{C}-\mathrm{D}$ and D-D clumping in methane: methods and preliminary results, Geochim. Cosmochim. Ac., 126, 169-191, 2014.

Stramma, L., Johnson, G. C., Sprintall, J., and Mohrholz, V.: Expanding oxygen-minimum zones in the tropical oceans, Science, 320, 655-658, 2008.

Suess, E.: Marine cold seeps, in: Handbook of Hydrocarbon and Lipid Microbiology, edited by: Timmis, K. N., Springer, Berlin, 187-203, 2010.

Sun, X., Jayakumar, A., and Ward, B. B.: Community composition of nitrous oxide consuming bacteria in the oxygen minimum zone of the Eastern Tropical South Pacific, Front. Microbiol., 8, 1183, https://doi.org/10.3389/fmicb.2017.01183, 2017.

Suntharalingam, P., Buitenhuis, E., Le Quere, C., Dentener, F., Nevison, C., Butler, J. H., Bange, H. W., and Forster, G.: Quantifying the impact of anthropogenic nitrogen deposition on oceanic nitrous oxide, Geophys. Res. Lett., 39, L07605, https://doi.org/10.1029/2011g1050778, 2012.

Sutka, R. L., Ostrom, N. E., Ostrom, P. H., Breznak, J. A., Gandhi, H., Pitt, A. J., and Li, F.: Distinguishing nitrous oxide production from nitrification and denitrification on the basis of isotopomer abundances, Appl. Environ. Microbiol., 72, 638-644, 2006.

Tait, D. R., Maher, D. T., Wong, W., Santos, I. R., Sadat-Noori, M., Holloway, C., and Cook, P. L.: Greenhouse gas dynamics in a salt-wedge estuary revealed by high resolution cavity ring-down spectroscopy observations, Environ. Sci. Technol., 51, 1377113778, 2017.

Thonat, T., Saunois, M., Pison, I., Berchet, A., Hocking, T., Thornton, B. F., Crill, P. M., and Bousquet, P.: Assessment of the theoretical limit in instrumental detectability of northern high-latitude methane sources using $\delta^{13} \mathrm{C}_{\mathrm{CH} 4}$ atmospheric signals, Atmos. Chem. Phys., 19, 12141-12161, https://doi.org/10.5194/acp-19-12141-2019, 2019.

Thornton, B. F., Geibel, M. C., Crill, P. M., Humborg, C., and Mörth, C.-M.: Methane fluxes from the sea to the atmosphere across the Siberian shelf seas, Geophys. Res. Letts., 43, 58695877, https://doi.org/10.1002/2016GL068977, 2016a.

Thornton, B. F., Wik, M., and Crill, P. M.: Doublecounting challenges the accuracy of high-latitude methane inventories, Geophys. Res. Lett., 43, 12569-12577, https://doi.org/10.1002/2016GL071772, 2016b.

Thornton, B. F., Prytherch, J., Andersson, K., Brooks, I. M., Salisbury, D., Tjernström, M., and Crill, P. M.: Shipborne eddy covariance observations of methane fluxes constrain Arctic sea emissions, Sci. Adv., 6, eaay7934, https://doi.org/10.1126/sciadv.aay7934, 2020.

Tian, H., Xu, R., Canadell, J. G., Thompson, R. L., Winiwarter, W., Suntharalingam, P., Davidson, E. A., Ciais, P., Jackson, R. B., Janssens-Maenhout, G., and Prather, M. J.: A comprehensive quantification of global nitrous oxide sources and sinks, Nature, 586, 248-256, 2020.
Tohjima, Y., Zeng, J., Shirai, T., Niwa, Y., Ishidoya, S., Taketani, F., Sasano, D., Kosugi, N., Kameyama, S., Takashima, H., and Nara, H.: Estimation of $\mathrm{CH}_{4}$ emissions from the East Siberian Arctic Shelf based on atmospheric observations aboard the R/V Mirai during fall cruises from 2012 to 2017, Polar Sci., 100571, https://doi.org/10.1016/j.polar.2020.100571, 2020.

Torn, M. S., Biraud, S., Agarwal, D., Keenan, T. F., Chan, S., Christianson, D.S., Chu, H., McNicol, G., Papale, D., Pastorello, G., and Stover, D. B.: AmeriFlux: Flux Synthesis and the Year of Methane, Abstract, American Geophysical Union Fall Meeting, San Francisco, TH13H, 2019.

Trimmer, M., Chronopoulou, P. M., Maanoja, S. T., UpstillGoddard, R. C., Kitidis, V., and Purdy, K. J.: Nitrous oxide as a function of oxygen and archaeal gene abundance in the North Pacific, Nat. Commun., 7, 1-10, 2016.

Upstill-Goddard, R. C.: Air-sea gas exchange in the coastal zone, Est., Coastal Shelf Sci., 70, 388-404, 2006.

Upstill-Goddard, R. C. and Barnes, J.: Methane emissions from UK estuaries: Re-evaluating the estuarine source of tropospheric methane from Europe, Mar. Chem., 180, 14-23, 2016.

Valentine, D. L.: Emerging topics in marine methane biogeochemistry, Annu. Rev. Mar. Sci., 3, 147-171, 2011.

Vieillard, A. M. and Fulweiler, R. W.: Tidal pulsing alters nitrous oxide fluxes in a temperate intertidal mudflat, Ecology, 95, 19601971, 2014.

Wanninkhof, R.: Relationship between wind speed and gas exchange over the ocean revisited, Limnol. Oceanogr.-Meth., 12, 351-362, 2014. Wang, D. T., Gruen, D. S., Lollar, B. S., Hinrichs, K. U., Stewart, L. C., Holden, J. F., Hristov, A. N., Pohlman, J. W., Morrill, P. L., Könneke, M., and Delwiche, K. B.: Nonequilibrium clumped isotope signals in microbial methane, Science, 348, 428-431, 2015.

Wankel, S. D., Ziebis, W., Buchwald, C., Charoenpong, C., de Beer, D., Dentinger, J., Xu, Z., and Zengler, K.: Evidence for fungal and chemodenitrification based $\mathrm{N}_{2} \mathrm{O}$ flux from nitrogen impacted coastal sediments, Nat. Commun., 8, 1-11, 2017.

Ward, B. B., Olson, R. J., and Perry, M. J.: Microbial nitrification rates in the primary nitrite maximum off southern-California, Deep-Sea Res., 29, 247-255, 1982.

Weber, T., Wiseman, N. A., and Kock, A.: Global ocean methane emissions dominated by shallow coastal waters, Nat. Commun., 10, 1-10, 2019.

Weinstein, A., Navarrete, L., Ruppel, C., Weber, T. C., Leonte, M., Kellermann, M. Y., Arrington, E. C., Valentine, D. L., Scranton, M. I., and Kessler, J. D.: Determining the flux of methane into Hudson Canyon at the edge of methane clathrate hydrate stability, Geochem. Geophy. Geosy., 17, 3882-3892, https://doi.org/10.1002/2016gc006421, 2016.

Weiss, R. F., Von Woy, F. A., and Salameh, P. K.: Surface water and atmospheric carbon dioxide and nitrous oxide Observations by shipboard automated gas chromatography: Results from expeditions between 1977 and 1990, Rep. S/0 92-11, Carbon Dioxide Inf. Anal. Cent., Oak Ridge Natl. Lab., Oak Ridge, Tennessee, USA, 1992.

Wells, N. S., Maher, D. T., Erler, D. V., Hipsey, M., Rosentreter, J. A., and Eyre, B. D.: Estuaries as sources and sinks of $\mathrm{N}_{2} \mathrm{O}$ across a land use gradient in subtropical Australia, Global Biogeochem. Cy., 32, 877-894, 2018. 
Whiticar, M. J.: Carbon and hydrogen isotope systematics of bacterial formation and oxidation of methane, Chem. Geology, 161, 291-314, 1999.

Wilson, S. T., Ferrón, S., and Karl, D. M.: Interannual variability of methane and nitrous oxide in the North $\mathrm{Pa}-$ cific Subtropical Gyre, Geophys. Res. Lett., 44, 9885-9892, https://doi.org/10.1002/2017GL074458, 2017.

Wilson, S. T., Bange, H. W., Arévalo-Martínez, D. L., Barnes, J., Borges, A. V., Brown, I., Bullister, J. L., Burgos, M., Capelle, D. W., Casso, M., de la Paz, M., Farías, L., Fenwick, L., Ferrón, S., Garcia, G., Glockzin, M., Karl, D. M., Kock, A., Laperriere, S., Law, C. S., Manning, C. C., Marriner, A., Myllykangas, J.-P., Pohlman, J. W., Rees, A. P., Santoro, A. E., Tortell, P. D., Upstill-Goddard, R. C., Wisegarver, D. P., Zhang, G.-L., and Rehder, G.: An intercomparison of oceanic methane and nitrous oxide measurements, Biogeosciences, 15, 5891-5907, https://doi.org/10.5194/bg-15-5891-2018, 2018.

Wyman, M., Hodgson, S., and Bird, C.: Denitrifying alphaproteobacteria from the Arabian Sea that express nosZ, the gene encoding nitrous oxide reductase, in oxic and suboxic waters, Appl. Environ. Microbiol., 79, 2670-2681, 2013.

Yang, M., Bell, T. G., Hopkins, F. E., Kitidis, V., Cazenave, P. W., Nightingale, P. D., Yelland, M. J., Pascal, R. W., Prytherch, J., Brooks, I. M., and Smyth, T. J.: Air-sea fluxes of CO2 and CH4 from the Penlee Point Atmospheric Observatory on the southwest coast of the UK, Atmos. Chem. Phys., 16, 5745-5761, https://doi.org/10.5194/acp-16-5745-2016, 2016.

Yang, W.-B., Yuan, C.-S., Huang, B.-Q., Tong, C., and Yang, L.: Emission characteristics of greenhouse gases and their correlation with water quality at an estuarine mangrove ecosystemthe application of an in situ on-site NDIR monitoring technique, Wetlands, 38, 723-738, 2018.

Yang, S., Chang, B. X., Warner, M., Weber, T. S., Bourbonnais, A., Santoro, A. E., Kock, A., Sonnerup, R., Bullister, J., Wilson, S. T., and Bianchi D.: New global reconstruction reduces the uncertainty of oceanic nitrous oxide emissions and reveals a vigorous seasonal cycle, P. Natl. Acad. Sci. USA, 117, 11954-11960, https://doi.org/10.1073/pnas.1921914117, 2020.
Yoshida, N. and Toyoda, S.: Constraining the atmospheric $\mathrm{N}_{2} \mathrm{O}$ budget from intramolecular site preference in $\mathrm{N}_{2} \mathrm{O}$ isotopomers, Nature, 405, 330-334, 2000.

Young, E. D., Kohl, I. E., Lollar, B. S., Etiope, G., Rumble III, D., Li, S., Haghnegahdar, M. A., Schauble, E. A., McCain, K. A., Foustoukos, D. I., and Sutclife, C.: The relative abundances of resolved ${ }^{l 2} \mathrm{CH}_{2} \mathrm{D}_{2}$ and ${ }^{13} \mathrm{CH}_{3} \mathrm{D}$ and mechanisms controlling isotopic bond ordering in abiotic and biotic methane gases, Geochim. Cosmochim. Ac., 203, 235-264, 2017.

Yu, L., Harris, E., Lewicka-Szczebak, D., Barthel, M., Blomberg, M. R., Harris, S. J., Johnson, M. S., Lehmann, M. F., Liisberg, J., Müller, C., Ostrom, N. E., Six, J., Toyoda, S., Yoshida, N., and Mohn, J.: What can we learn from $\mathrm{N}_{2} \mathrm{O}$ isotope data? - Analytics, processes and modelling, Rapid Comms. Mass Spec., 34, e8858, https://doi.org/10.1002/rcm.8858, 2020.

Yurganov L., Muller-Karger F., and Leifer I.: Methane increase over the Barents and Kara Seas after the autumn pycnocline breakdown: satellite observations, Adv. Polar Sci., 30, 382-390. https://doi.org/10.13679/j.advps.2019.0024, 2019.

Zamora, L. M. and Oschlies, A.: Surface nitrification: A major uncertainty in marine $\mathrm{N}_{2} \mathrm{O}$ emissions, Geophys. Res. Lett., 41, 4247-4253, https://doi.org/10.1002/2014g1060556, 2014.

Zappa, C. J., Raymond, P. A., Terray, E. A., and McGillis, W. T.: Variation in surface turbulence and the gas transfer velocity over a tidal cycle in a macro-tidal estuary, Estuaries, 26, 1401-1415, 2003.

Zhang, G., Zhang, J., Liu, S., Ren, J., Xu, J., and Zhang, F.: Methane in the Changjiang (Yangtze River) Estuary and its adjacent marine area: riverine input, sediment release and atmospheric fluxes, Biogeochemistry, 91, 71-84, 2008.

Zhang, J., Zhan, L., Chen, L., Li, Y., and Chen, J.: Coexistence of nitrous oxide undersaturation and oversaturation in the surface and subsurface of the western Arctic Ocean, J. Geophys. Res., 120, 8392-8401, https://doi.org/10.1002/2015JC011245, 2015. 